\title{
Revised correlation of the Frasnian-Famennian boundary and Kellwasser Events (Upper Devonian) in shallow marine paleoenvironments of New York State
}

\author{
Andrew M. Bush a,b, ${ }^{\text {, }}$, Jayme D. Csonka ${ }^{\mathrm{b}}$, Graziella V. DiRenzo ${ }^{\mathrm{a}, 1}$, D. Jeffrey Over ${ }^{\mathrm{c}}$, J. \\ Andrew Beard ${ }^{\mathrm{b}}$
}

${ }^{\text {a }}$ Department of Ecology and Evolutionary Biology, University of Connecticut, 75 North Eagleville Road, U-3043, Storrs, CT 06269-3043, USA

${ }^{\mathrm{b}}$ Center for Integrative Geosciences, University of Connecticut, 354 Mansfield Road, U1045, Storrs, CT 06269-1045, USA

c Department of Geological Sciences, SUNY College at Geneseo, Geneseo, NY 14454, USA

${ }^{1}$ Present address: Department of Biology, University of Maryland, 4219 BiologyPsychology Building, College Park, MD 20742, USA

* Corresponding author. Tel.: +1 111860486 9359; fax: +1 1118604866364 . E-mail address: andrew.bush@uconn.edu (A.M. Bush).

E-mail addresses of co-authors: jayme.csonka@uconn.edu, gdirenzo@umd.edu, over@geneseo.edu, james.beard@uconn.edu 


\section{ABSTRACT}

2 The Frasnian-Famennian boundary (Upper Devonian) is exposed in a $200 \mathrm{~km}$-long outcrop belt

3 in New York State, with deeper paleoenvironments to the west and shallower ones to the east.

4 Geochronology in the eastern end of the outcrop belt has been based primarily on

5 lithostratigraphic correlation with western sections, which were dated using conodonts. We

6 collected conodonts and brachiopods from several measured sections and numerous other

7 localities, and these collections suggest that these east-west lithostratigraphic correlations require

8 revision. We correlate the Wiscoy Formation with the upper Angola Formation and the

9 Canaseraga with the upper Hanover. Thus, the Canaseraga Formation contains the Frasnian-

10 Famennian boundary and Upper Kellwasser Event, and the dark shale above the Wiscoy is

11 equivalent to the Pipe Creek Formation and Lower Kellwasser Event. These new correlations

12 imply that the Lower Kellwasser Event had greater impact on the shelly benthos of New York

13 than the Upper Kellwasser, at least for the subset of taxa examined here. All strophomenid

14 brachiopods and rugose corals were extirpated at the Lower Kellwasser, along with numerous

15 other brachiopods. The final species of atrypid brachiopod persisted to the Upper Kellwasser.

17 Keywords: Late Devonian, mass extinction, black shale, Chemung, Appalachian Basin,

18 Pennsylvania

\section{1. Introduction}

21 Extinction events in the Late Devonian caused considerable biotic turnover and

22 ecological change (e.g., Schindler, 1993; McGhee, 1996, 2013; House, 2002; Copper, 2002;

23 McGhee et al., 2004; Sallan and Coates, 2010; Christie et al., 2013). Two of these extinctions, 
24 the Lower and Upper Kellwasser Events (LK and UK), occurred during the late Frasnian and

25 coincided with the deposition of the Lower and Upper Kellwasser limestones, organic-rich

26 deposits found across Europe and northern Africa (Schindler, 1993; Joachimski and Buggisch,

27 1993). At several deep-water locations in western New York State, Over $(1997,2002)$ identified

28 the temporal equivalents of the Kellwasser Events using conodont biostratigraphy. To the east of

29 these locations, shallower-water facies are exposed, macrofossils are common, conodonts are

30 rare, and geochronology is based primarily on lithostratigraphic correlations with the deeper-

31 water sections in western New York (Chadwick, 1935; Pepper and deWitt, 1950, 1951; Rickard,

32 1964, 1975; Smith and Jacobi, 2000). However, new collections of brachiopods and conodonts

33 indicate that the Frasnian-Famennian (F-F) boundary and the Kellwasser Events have generally

34 been misplaced in the shallow-water, "Chemung" paleoenvironments at the eastern end of the

35 outcrop belt. We suggest alternate correlations that will serve as the basis for future studies of

36 Late Devonian extinction dynamics in the Appalachian Basin.

\section{2. Geologic Setting and Stratigraphy}

39 During the Late Devonian, sediments shed from the Acadian Mountains were deposited

40 in the Appalachian Foreland Basin as part of the prograding clastic wedge of the "Catskill Delta"

41 (Woodrow and Sevon, 1985; Filer, 2003; Ver Straeten, 2009). Upper Frasnian and lower

42 Famennian strata are exposed in New York in an outcrop belt stretching from Lake Erie in the

43 west to the Pennsylvania border south of Corning (Fig. 1A, B), with paleoenvironments

44 shallowing eastwards. The stratigraphy and paleoecology of these strata (and correlative rocks to

45 the south) have been addressed by numerous authors, including McGhee (1976), McGhee and

46 Sutton (1981, 1983, 1985), Sutton and McGhee (1985), Roen and deWitt (1984), Van Tassell 
47 (1987), Warne and McGhee (1991), Castle (2000), Murphy et al. (2000), Smith and Jacobi

48 (2001), Day and Over (2002), Filer (2002, 2003), Rode and Lieberman (2004), Stigall Rode and

49 Lieberman (2005), Bond and Wignall (2008), Bush and Brame (2010), Christie et al. (2013), and

50 McClung et al. (2013).

51 In western New York, upper Frasnian and lower Famennian strata include shales

52 assigned to the Angola, Pipe Creek, Hanover, Dunkirk, South Wales, and Gowanda formations

53 (Fig. 2). Over $(1997,2002)$ identified the Pipe Creek as the temporal equivalent of the LK and a

54 thin black shale interval in the Hanover located $3 \mathrm{~m}$ or less below the contact with the Dunkirk as

55 the UK equivalent. The Upper Devonian is poorly exposed in parts of Wyoming County, but

56 outcrops become common again in the Genesee River valley and eastwards (Fig. 1B; also see Fig.

571 of Pepper and deWitt, 1950).

58 In the eastern part of the outcrop belt, silt- and sand-rich strata of the Nunda, Wiscoy (Fig.

59 3D), and Canaseraga (Fig. 3B) formations are separated by gray and dark gray shales (Fig. 3A,

60 C) that have been correlated with the shales in the west in various ways by different authors,

61 reflecting the challenges of correlation when facies changes are substantial and biostratigraphic

62 and other geochronological data are absent. Chadwick $(1919,1923,1924,1935)$ correlated the

63 Pipe Creek of western New York with a shale bed above the Nunda, and he correlated the

64 Hanover and Dunkirk with the Wiscoy and Canaseraga, respectively (Fig. 2A). At the time, the

65 Wiscoy referred to all of the shalier strata along Wiscoy Creek (WSC in Fig. 1B; Clarke, 1899;

66 Clarke and Luther, 1908) - that is, all strata below the Canaseraga (Mills-Mills of Smith and

67 Jacobi, 2000).

Like Chadwick, Pepper and deWitt $(1950,1951)$ and Pepper (1954) placed the Pipe

69 Creek atop the Nunda, but they placed the Dunkirk and the top of the Wiscoy lower in the 
70 section and named the black shale on top the Canaseraga the Hume (Fig. 2B). These basic

71 correlations have been used by many authors since (e.g., Rickard, 1964; Smith and Jacobi, 2000,

72 2001, 2006) and were ensconced in the geologic map of New York (Rickard and Fisher, 1970).

73 However, these correlations did not receive universal support. After examining numerous

74 well logs and outcrops, Roe (1975) correlated the Dunkirk with the Hume Shale, in contrast with

75 Pepper and deWitt $(1950,1951)$ (Fig. 2C). The Pipe Creek remained correlated with the shale

76 above the Nunda, such that all strata above the Nunda and below the "Hume" were correlated

77 with the Hanover (similar to Fig. 2A, but with the Canaseraga equivalent to the upper Hanover,

78 not the Dunkirk). In the eastern portion of the outcrop belt, Roe (1975) referred to the dark shale

79 that Pepper and deWitt $(1950,1951)$ called the Dunkirk as the "Pipe Creek 2", and he treated the

80 Canaseraga as part of the Wiscoy Formation (Fig. 2C). These correlations were followed by

81 Rickard (1975), and, implicitly, by McGhee and Sutton (1981). Roe's (1975) work was never

82 published, and neither he nor Rickard (1975) provided a detailed justification for including the

83 Canaseraga in the Wiscoy. As a result, the rationale for these correlations has remained murky,

84 and, furthermore, it is not always clear which definition of the Wiscoy is employed in some

85 subsequent works. Smith and Jacobi (2000) criticized Rickard's (1975) placement of the "Hume"

86 directly on top of the Wiscoy, because these units (as often defined) are separated by more than

$8750 \mathrm{~m}$ of strata at Wiscoy Creek (WSC and MIL, Fig. 1). However, Roe's (1975) work suggests

88 that these strata were not omitted per se; rather, the Wiscoy was defined to encompass the

89 Canaseraga. Here, we follow Pepper and deWitt's (1950) definition for the top of the Wiscoy

90 (Fig. 2B) because it corresponds to a major lithologic transition that is recognizable across the

91 region (see Smith and Jacobi, 2000, 2001, for further details). 
The base of the Canaseraga Formation has also been defined in various ways. Chadwick

93 (1923) proposed the name "Canaseraga ss" for strata between the Wiscoy and the Gowanda.

94 Chadwick (1924) elaborated further, proposing the name "Canaseraga sandstone" for the " 150

95 feet of heavy arenaceous beds" exposed along Slader Creek near Canaseraga, New York

96 (location 29 on Fig. 1C). Given the original meaning of the Wiscoy, discussed above (Clarke

97 1899; Clarke and Luther 1908), and the description of the type section, Chadwick's Canaseraga

98 sandstone only included the sandy interval referred to as "Mills-Mills" by Smith and Jacobi

99 (2000, 2001, 2006). However, Pepper and deWitt (1951) also included an interval of interbedded

100 shales and thin siltstones that underlies the more massive silt/sandstones. Smith and Jacobi (2000,

101 2001) used the informal name "Mills-Mills Formation" to distinguish the sandy beds, later

102 proposing it as a formal name (Smith and Jacobi 2006).

103 Here, we define the Canaseraga as equivalent to the "Mills-Mills" as illustrated by Smith

104 and Jacobi (2001). The base of the Canaseraga is best placed at the base of the sandy beds, where

105 it marks a major lithologic transition that is easily recognizable across the outcrop belt. This

106 placement also matches the original definition of Chadwick $(1923,1924)$ by our interpretation.

\section{3. Methods}

109 Fossils were collected bed-by-bed through measured sections in Hornell (BCP), Cameron

110 (CAM), and Tioga, Pennsylvania (TGB), that expose the upper Wiscoy Formation and overlying

111 strata (see Table 1 and Fig. 1 for locality information). Section TGB was illustrated previously

112 by Berg et al. (1981, p. 156) and Castle (2000, p. 907) and is mapped as the Lock Haven

113 Formation, a name applied to Upper Devonian shallow marine strata in Pennsylvania (Berg et al.,

114 1980). Section CAM was previously shown by Pepper and deWitt (1951), who extrapolated the 
115 lithology of some covered intervals. These prior works did not include detailed faunal data.

116 Additional samples from numerous other locations that expose the Wiscoy and overlying strata

117 were also examined (Fig. 1, Table 2), some of which were used previously by Christie et al.

118 (2013).

119 International biostratigraphic correlation in the Upper Devonian is based primarily on

120 conodonts (e.g., Ziegler, 1962; Klapper, 1989, 1997; Ziegler and Sandberg, 1990; Klapper et al.,

121 1994; Over, 1997, 2002), and several were located via visual inspection of rock samples.

122 Rhynchonelliform brachiopods were extremely abundant at many of our localities and have been

123 used previously for regional correlations within the Appalachian Basin (e.g., McGhee, 1976;

124 McGhee and Dennison, 1980; Dutro, 1981; Brame, 2001). The atrypid brachiopods are of

125 particular biostratigraphic value because they go extinct by the F-F boundary (Copper, 1998;

126 Day, 1998). For this study, we tabulated occurrences of strophomenid, orthid, atrypid, athyrid,

127 and a subset of spriferid and spiriferinid brachiopods. Taxa were identified with reference to type

128 material and previous works (Hall, 1867; Hall and Whitney, 1858; Hall and Clarke, 1892, 1894;

129 Williams, 1908; Clarke and Swartz, 1913a,b; Caster, 1930; Stainbrook, 1940, 1942, 1945; Butts,

130 1941; Williams, 1953; Greiner, 1957; Cooper and Dutro,1982; Rossbach, 1992; Linsley, 1994;

131 Day and Copper, 1998; Brame, 2001; Day and Over, 2002; Stigall Rode, 2005). Many of the

132 species are long overdue for taxonomic revision, but for now we use previously published names

133 pending revisions. Rugose corals were noted but not identified specifically; for information on

134 Chemung rugose corals, see Stumm (1960) and Sorauf $(1978,1987)$. Bivalves, bryozoans,

135 nautiloids, gastropods, and crinoid debris were present but not examined in detail.

136 Brachiopods were preserved as molds or as calcite shells, which generally could not be

137 extracted from the matrix. Many specimens were exposed using hammers, chisels, and a 
138 hydraulic rock splitter, and some were further prepared with a vibropick. Some samples were

139 treated in dilute $\mathrm{HCl}$ to reveal molds. Whole shells could be extracted easily from the matrix at

140 several localities that exposed the uppermost $5 \mathrm{~m}$ of the Wiscoy Formation (e.g., locations 13, 16,

141 and $\mathrm{BCP})$.

142

143 4. Data

144 Numerous macrofossil species last occurred near the top of the Wiscoy at sections BCP,

145 CAM, and TGB (Fig. 4); these include all strophomenid brachiopods (e.g., Fig. 5A-D) and

146 rugose corals, both of which suffered globally in the Frasnian extinctions (e.g., Sorauf and

147 Pedder, 1986; Rong and Cocks, 1994) and do not occur above the Wiscoy in New York (Oliver

148 and Sorauf, 1981, 1983; Dutro, 1981)1. Two atrypid species were found in the Wiscoy

149 (Pseudoatrypa devoniana and Spinatrypa hystrix; Fig. 5E), neither of which continued into the

150 overlying strata. Other victims include several orthids (Fig. 5G-O), a spiriferid, and a spiriferinid.

151 Species that ranged through the entire interval (e.g., Tylothyris mesacostalis, Schizophoria

152 impressa) were excluded for clarity (Fig. 4). At TGB, Spinatrypa hystrix and Schizophoria

153 amanaensis also occurred just above the dark shale that overlies the Wiscoy (Fig. 4C). However,

154 these fossils were worn and occurred in a high-energy, rippled conglomerate that was unique in

155 the section. This is the only location where these taxa occurred above this shale, and we interpret

156 them as reworked due to their physical appearance and the sedimentology of the enclosing bed.

\footnotetext{
${ }^{1}$ Dutro (1981) indicated that Douvillina arcuata, a strophomenid, might extend above the Wiscoy, but marked postWiscoy occurrences with a question mark. We have not observed this species above the Wiscoy in our collections or museum collections.
} 
The dark shale above the Wiscoy is overlain by interbedded shales and silts, referred to

158 the South Wales Formation by Smith and Jacobi (2000, 2001). Several species first occur in

159 these beds (Fig. 4), including Spinatrypa cf. planosulcata (Fig. 5F), “Thiemella” leonensis (Fig.

160 5P-R), and "Athyris" angelica. This turnover in the brachiopod fauna can be recognized across

161 the eastern portion of the outcrop belt (Table 2).

162 At the Mills-Mills locality on Wiscoy Creek (MIL in Fig. 1B), the Canaseraga Formation

163 consists of two sandy intervals separated by an interval of interbedded shales, siltstones, and

164 sandstones (see Fig. 6d of Smith and Jacobi, 2001). Unfortunately, the Wiscoy Creek section has

165 few body fossils, and we have not yet examined a fossiliferous section through the entirety of the

166 Canaseraga in shallower-water settings, presumably because the finer-grained interval is often

167 poorly exposed. However, outcrops of the sandy beds are plentiful (e.g., Fig. 3B), and, based on

168 current collections, Spinatrypa cf. planosulcata occurs in the lower, but not the upper, sandy

169 beds of the Canaseraga, as determined by contact with under- and overlying strata.

170 The stratigraphic ranges of brachiopods observed here (Fig. 6) are somewhat different

171 from previous range compilations. For example, some species that we found in the Wiscoy were

172 reported previously to last occur in the Nunda (Dutro, 1981), including Stainbrookia infera (Fig.

173 5J-L) and Strophonelloides coelata (Fig. 5B). Several taxa previously reported from the Wiscoy

174 were not observed (e.g., Cariniferella; Dutro, 1981; McGhee and Sutton, 1981).

175 At section BCP in Hornell, the conodont Palmatolepis winchelli (Fig. 7A) was recovered

176 from the dark shale above the Wiscoy (Fig. 4A). Ancyrognathus symmetricus (Fig. 7B) was

177 recovered from the "Hume" Shale at Mills-Mills (MIL in Figs. 1B, 8). 
181 deWitt (1950, 1951), Rickard (1964), Rickard and Fisher (1970), and Smith and Jacobi (2000,

182 2001) imply that the F-F boundary and UK event should lie at or near the top of the Wiscoy

183 Formation (Fig. 2B), so the overlying strata should contain no Frasnian taxa unless there was

184 reworking. However, the conodont Palmatolepis winchelli (Fig. 7A), a wide-ranging upper

185 Frasnian taxon known from the Pipe Creek and upper Hanover further to the west (Over, 1997),

186 occurs in the dark shale above the Wiscoy (Fig. 4A). In addition, atrypid brachiopods - which

187 elsewhere go extinct at the end of the Frasnian (e.g., Copper, 1998; Day, 1998)—persist into the

188 lower Canaseraga Formation, at least $60 \mathrm{~m}$ above the Wiscoy at Cameron (Fig. 4B).

189 Characteristic Frasnian taxa could occur in strata commonly mapped as lower Famennian

190 for several reasons. The strata could be Frasnian in age, or nominally Frasnian taxa could have

191 survived into the Famennian in this part of New York. Alternatively, the fossils could have been

192 reworked upwards from the Wiscoy. However, the fossils occur high above the Wiscoy at

193 multiple localities (Fig. 4) and do not show signs of reworking; indeed, some atrypid specimens

194 have delicate spines preserved. We also find it unlikely that New York was a "refugium" for

195 both conodonts and brachiopods that are known to go extinct elsewhere at the end of the

196 Frasnian. Miscorrelation is therefore highly probable in Fig. 2B.

197 The Famennian conodont Ancyrognathus symmetricus (Fig. 7B) was recovered in the

198 "Hume" Shale, which overlies the Canaseraga, at Mills-Mills (MIL in Figs. 1B, 8). This is the

199 first record of this species from New York, but it is known from Upper triangularis Zone strata

200 of the Dunkirk-equivalent lower Gassaway Member of the Chattanooga Shale in Tennessee

201 (Over, 2007). Spinatrypa cf. planosulcata (Fig. 5F) occurs as high as the lower sandy beds of the

202 Canaseraga Formation (Figs. 4B, 6), suggesting that these beds are Frasnian. It has not been 
203 found in the upper sandy beds, but it is unknown if it persists into the muddier beds between the

204 two sandy intervals due to poor exposure. These fossils constrain the F-F boundary to the base of

205 the Hume, the upper sandy beds of the Canaseraga Formation, or the finer interval between the

206 lower and upper sands. We tentatively place the F-F boundary and UK equivalent in the shalier

207 interval between the two sandy pulses of the Canaseraga (Fig. 8), consistent with the

208 disappearance of atrypids from the lower to upper sands and the placement of the boundary

209 below the Hanover-Dunkirk contact in the western sections studied by Over (1997, 2002).

210 However, exact placement of the boundary in the eastern portion of the outcrop belt requires

211 additional analysis of complete sections.

212 The "Hume" shale and overlying gray shales of the Caneadea sit at or near the base of the

213 Famennian according to our biostratigraphic data, suggesting that they are temporally equivalent

214 to the Dunkirk, South Wales, and Gowanda formations of western New York, providing support

215 for the correlation of these units by Roe (1975) (Fig. 2C). The Dunkirk marks the most extensive

216 transgression since the Rhinestreet event and the last thick transgressive shale of the Upper

217 Devonian in New York (Rickard, 1964, 1975; Filer, 2003), and the Hume-Caneadea shale

218 succession is extremely thick. For example, there is $\sim 50 \mathrm{~m}$ of uninterrupted shale at section ERC

219 (Fig. 8), and the next $50 \mathrm{~m}$ is dominated by shale with some beds of silt or fine sand (also see Fig.

2205 in Smith and Jacobi, 2001). In contrast, the shale above the Wiscoy is much thinner (Fig. 8).

221 These revised correlations solve the odd geometry of the "Hume" Shale on some previous

222 correlation charts, which show it pinching out both landward and basinward (Fig. 2B); in Fig. 2D,

223 it is simply the eastward extension of the Dunkirk (also see Roe, 1975; Rickard, 1975).

224 Occurrences of brachiopods and conodonts indicate that the dark shale above the Wiscoy

225 and below the Canaseraga is upper Frasnian, not Famennian as implied in Fig. 2B. Roe (1975) 
226 and Rickard (1975) also placed it in the Frasnian (Fig. 2C), but they did not correlate it with any

227 of the named black shales from western New York, and Rickard (1975) showed it pinching out

228 both landward and basinward, similar to the "Hume" Shale in Fig. 2B. We propose that the shale

229 above the Wiscoy correlates with the Pipe Creek Formation (LK equivalent), in contrast with

230 previous interpretations. It is approximately the same thickness as the Pipe Creek in western

231 New York (up to $7 \mathrm{~m}$ in the west and up to $15 \mathrm{~m}$ in the east; Fig. 8), and, as in western New

232 York, it is a "persistent, massive, petroliferous black shale" (Pepper and deWitt, 1950).

233 Previously, the Pipe Creek was placed above the Nunda in the eastern part of the outcrop belt,

234 but there is no dark shale at this horizon from Hornell eastwards; Pepper and deWitt (1950) and

235 Pepper (1954) presumed that it pinched out. However, it is persistent and easily recognizable in

236 deeper-water settings in New York, and Filer $(2002,2003)$ found that it persisted shorewards in

237 the subsurface of West Virginia. Likewise, the shale above the Wiscoy (as we define it) is

238 regionally extensive and easily recognizable in the shallower end of the outcrop belt, but was not

239 correlated with a major dark shale interval in western New York by Rickard (1975). With the

240 new correlations (Fig. 2D), the Pipe Creek is recognizable throughout New York and into

241 northern Pennsylvania (Figs. 3C, 4, 8).

242 In sum, the following correlations are proposed between the western and eastern portions

243 of the New York outcrop belt (Figs. 2D, 8): (1) the Wiscoy Formation correlates with the upper

244 part of the Angola, not with the Hanover; (2) the dark shale above the Wiscoy correlates with the

245 Pipe Creek, not the Dunkirk; (3) the strata overlying this dark shale ("lower Hanover equivalent"

246 in Figs. 2D , 4, 8) correlate with the lower Hanover Formation, not the South Wales; (4) the

247 Canaseraga is coeval with the upper Hanover Formation; (5) the "Hume" Shale is equivalent to

248 the Dunkirk; and (6) the Caneadea is correlative with the South Wales and Gowanda Formations. 
249 Given these revised correlations, the Wiscoy and Canaseraga formations should be reassigned to

250 the West Falls and Java groups, respectively (Fig. 2D).

\section{6. Subsurface}

Filer (2002) recognized 11 late Frasnian transgressive-regressive cycles in gamma-ray

254 logs from the Appalachian Basin, including western New York and West Virginia (also see Roe, 255 1975; Roen and deWitt, 1984). We downloaded well logs from the Empire State Oil and Gas

256 Information System (2013) to determine whether these cycles could be recognized in the more

257 onshore environments of the eastern portion of the New York outcrop belt. Black shales are

258 indicated by elevated gamma-ray radiation and clean sands by lower values (Filer, 2002).

259 In western New York, the Dunkirk manifests as a persistent shift to high gamma ray

260 values that marks the top of Filer's (2002) cycle 11 (Fig. 9A, which shows the same log as Fig. 2

261 of Filer, 2002). The Pipe Creek defines the base of cycle 8 and is marked by a thinner interval of

262 positive values. Both of these deflections are apparent in a log from Steuben County (Fig. 9B)

263 that was recorded $7 \mathrm{~km}$ from CAM (Fig. 4B) and $4 \mathrm{~km}$ from the Roosa School section of Pepper

264 and deWitt (1951), which is similar to CAM. The pronounced shift to elevated values at the base

265 of the Dunkirk is obvious, and the Pipe Creek lies within a broad elevated interval that also

266 includes the shaly strata of the upper Wiscoy and lower Hanover equivalent. Cycles 9 and 10 are

267 also visible, as is the broad interval of low values that comprises cycle 7 . The $\mathrm{cm}$-scale lithologic

$268 \log$ of the CAM section (Fig. 9C) corresponds well with the nearby Steuben County well log.

269 The outcrop section does not extend to the top of the Canaseraga or to the overlying Dunkirk

270 Shale, but the shale outcrops nearby (ERC in Figs. 1, 8). Several of the cycles are also apparent

271 in gamma-ray logs measured by Castle (2000) from the Tioga outcrops; the Pipe Creek shows up 
272 as a strong but thin deflection towards high values and the Dunkirk as a persistent interval of

273 high values (Fig. 9D). These results reinforce the potential of gamma-ray logs as a useful tool in

274 further correlations of these strata at other sites in New York and Pennsylvania.

275

276 7. Remaining Questions

277 Additional conodonts from the eastern end of the outcrop belt would be useful in

278 validating these correlations, although they are rare and difficult to locate in coarser siliciclastic

279 sediments. Carbon isotope chemostratigraphy could provide an independent check on the

280 proposed correlations and positions of the Kellwasser Events (e.g., preliminary results presented

281 by Beard et al., 2014). Detailed correlation of the Wiscoy Creek section with sections to the west

282 (e.g., Java Village) could be helpful as well. Critically, the position of the UK needs to be

283 identified precisely in the eastern portion of the outcrop belt. Presuming that these revised

284 correlations are confirmed, the east-west correlations within the West Falls and Canadaway

285 Groups should be re-examined as well. Previously, the uppermost Angola was correlated with

286 the Nunda, but if it correlates with the Wiscoy, then the Nunda must be correlative with another

287 portion of the Angola (Fig. 2D). The Caneadea has been divided into several members (Smith

288 and Jacobi, 2000), and further work could provide more detailed correlations with the South

289 Wales-Gowanda succession in the west.

290 Correlations with the central and southern Appalachians could also be re-examined. In

291 West Virginia, McGhee (1977) placed the F-F boundary within the Pound Member of the

292 Foreknobs Formation, which is typically considered correlative with the Wiscoy of New York.

293 Biostratigraphic evidence presented here suggests that the Pound actually correlates with the

294 Canaseraga because the lower portion of each contains the last Spinatrypa and the first "Athyris" 
295 angelica (Figs. 4, 6). In his analysis of gamma-ray logs, Filer (2002) correlated the Pound with

296 the upper portion of the Hanover Formation, which again would make it correlative with the

297 Canaseraga given the correlations outlined in Fig. 2D. Correlations between New York and

298 Pennsylvania should be re-evaluated as well (e.g., Warne and McGhee, 1999).

299 Revised correlations could also provide new insights into Upper Devonian sedimentology

300 and sequence stratigraphy. Smith and Jacobi $(2000,2001)$ analyzed the sedimentology and

301 sequence stratigraphy of the F-F boundary interval in Allegheny County, but expanding their

302 analyses to the other sections discussed herein would be valuable. Using the older correlations,

303 they noticed dramatic changes in the thicknesses of some units across the basin and suggested

304 that they resulted from syndepositional faulting that caused variable accommodation space, but

305 the role of faulting should be evaluated in light of these new correlations. Baird and Jacobi

306 (1999) described a sandstone bed that occurred within the Pipe Creek Shale in the South Wales-

307 Varysburg region of New York, to the west of our field area. In some localities, most or all of the

308 lower Pipe Creek appeared to have been removed by erosion during or prior to deposition of this

309 sandstone. Given the revised correlation of the Pipe Creek (Fig. 2D), this depositional event

310 could be re-evaluated across the basin. Finally, Boyer and Seeger (2012) examined oxygen levels

311 during the deposition of the UK in western NY using geochemical proxies and ichnofabrics, and

312 these studies could be extended into shallower water using these correlations.

\section{8. Implications for Kellwasser extinctions}

315 We ascribe the extinction at or near the top of the Wiscoy Formation to the LK event, not

316 the UK, as implied by some previous correlations (Fig. 2B). At this horizon, all strophomenid

317 brachiopods and rugose corals were extirpated (Figs. 4, 6). In other regions, strophomenids do 
318 not suffer as extensively at the LK, but suffer additional extinctions at the UK (e.g., Cooper and

319 Dutro, 1982; Day, 2010). All existing atrypids also went extinct, although Spinatrypa cf.

320 planosulcata appears in the overlying strata, presumably through migration. Several other

321 species of brachiopods last occur in the upper Wiscoy as well. These likely reflect extinction and

322 not facies control because the Canaseraga and underlying Hanover-equivalent beds represents a

323 range of facies generally similar to that of the Wiscoy, and we have sampled both intervals at

324 many localities along a depth transect (Fig. 1, Table 2). Possible exceptions include Schizophoria

325 amanaensis and Stainbrookia infera, which appear to have had a narrow environmental range,

326 only occurring in the transgressive interval in the upper $\sim 5 \mathrm{~m}$ of the Wiscoy. At least within the

327 subset of macrofaunal taxa considered here, the UK extinction appears to have had less effect

328 than the LK in New York (Fig. 6).

329 The LK extinction was previously placed at the top of the Nunda, and according to Dutro

330 (1981), numerous species last occur in this unit. Dutro emphasized that his results were

331 preliminary pending further field work and taxonomic revision, and we have found several

332 species in the Wiscoy that he shows last occurring in the Nunda; detailed comments on turnover

333 from the Nunda to the Wiscoy require further field work.

\section{9. Conclusions}

$336 \quad$ Upper Frasnian and lower Famennian strata of New York State were miscorrelated

337 between deeper-water sections in the west and shallower-water sections in the east. New

338 collections of conodonts and brachiopods from shallow-water, "Chemung" paleoenvironments

339 indicate that the dark shale above the Wiscoy Formation is correlative with the Pipe Creek and

340 that the "Hume" is correlative with the Dunkirk. Thus, extinctions at the top of the Wiscoy 
341 correspond with the Lower Kellwasser Event, not the Upper Kellwasser. These extinctions are

342 substantial and include all rugose corals and strophomenid brachiopods. The Upper Kellwasser

343 Event and Frasnian-Famennian boundary are hypothesized to fall within the Canaseraga

344 Formation, although additional work is needed to place the boundary precisely. These

345 correlations establish a temporal framework for further studies of biotic change and mass

346 extinction in shallow-water facies of the Appalachian Basin.

348 Acknowledgments

349 Thanks to G.C. Baird, R.K. Bambach, R.I. Brame, C.E. Brett, D.L. Boyer, M. Christie, J.E. Day, 350 P.R. Getty, G.G. Gonzalez, J. Hooten, S. Hsieh, C.A. Ver Straeten, G. Waldron, J. Wilford, and

351 the ESOGIS database, run by the Reservoir Characterization Group at the New York State

352 Museum. Special thanks to J.L. Payne for breaking lots of rocks in the field and T.D. McCarthy

353 for breaking them some more in the lab. G.C. Baird and D.L. Boyer provided excellent reviews,

354 and the USGS Field Records Collection provided copies of unpublished field notes and other

355 materials. For access to museum collections, thanks to E. Landing, F. Mannolini, and L.

356 VanAller Hernick at the New York State Museum, B. Hussaini at the American Museum of

357 Natural History, S. Butts at the Yale Peabody Museum, R.M. Sullivan at the State Museum of

358 Pennsylvania, and M. Florence and D. Chaney at the Smithsonian Institution. Many thanks to the

359 Petersons of Hornell, the Williams of Cameron, and other land owners for access to collection

360 localities. This work was supported by NSF grant EAR-0922186 to A.M. Bush, as well as by the

361 Department of Earth and Planetary Sciences at Harvard University and the University of

362 Connecticut Research Foundation. 


\section{References}

365 Baird, G.C., Jacobi, R., 1999. "Nunda Sandstone" depositional event in the Pipe Creek black

Berg, T.M., Edmunds, W.E., Geyer, A.R., Glover, A.D., Hoskins, D.M., MacLachlan, D.B.,

Beard, J.A., Bush, A.M., Hren, M.T., Csonka, J.D., 2014. An expanded $\delta^{13} \mathrm{Corg}_{\text {record through }}$ the Lower Kellwasser Event (Late Devonian) in the "Catskill Delta" of New York. Geological Society of America Abstracts with Programs 46, 131. shale, South Wales-Varysburg area, New York, in: Baird, G.C., Lash, G.G. (Eds.), Field Trip Guidebook, $71^{\text {st }}$ Annual Meeting, New York State Geological Association, Fredonia, NY, pp. Sun B1- Sun B2.

Root, S.I., Sevon, W.D., Socolow, A.A., Miles, C.E., Kuchinski, J.G., 1980. Geologic map of Pennsylvania, $2^{\text {nd }}$ ed.: Pennsylvania Geological Survey, 4th ser., Map 1, scale 1:250,000.

Berg, T.M., Crowl, G.H., Edmunds, W.E., Luce, P.B., Sevon, W.D., Wilshusen, J.P., Woodrow, D.L., 1981. Geology of Tioga and Bradford Counties, Pennsylvania. Guidebook for the $46^{\text {th }}$ Annual Field Conference of Pennsylvania Geologists, Pennsylvania Geological Survey, Harrisburg, Pennsylvania.

Bond, D.P.G., Wignall, P.B., 2008. The role of sea-level change and marine anoxia in the Frasnian-Famennian (Late Devonian) mass extinction. Palaeogeography, Palaeoclimatology, Palaeoecology 263, 107-118.

Boyer, D.L, Seeger, E., 2012. Rate and magnitude of oxygen stress leading into and out of the Kellwasser Event in New York State. Geological Society of America Abstracts with Programs 44, 185. 
Brame, R.I., 2001. Revision of the Upper Devonian in the central-southern Appalachian Basin: biostratigraphy and lithostratigraphy. Unpublished Ph.D. Thesis, Virginia Tech, Blacksburg, Virginia.

Bush, A.M., Brame, R.I., 2010. Multiple paleoecological controls on the composition of marine fossil assemblages from the Frasnian (Late Devonian) of Virginia, with a comparison of ordination methods. Paleobiology 36, 573-591.

Butts, C. 1941. Geology of the Appalachian Valley in Virginia: Part II: Fossil Plates and Explanation. Virginia Geological Survey Bulletin 52.

Caster, K.E., 1930. Higher fossil faunas of the upper Allegheny. Bulletins of American Paleontology, 15(58), 142-316.

Castle, J.W., 2000. Recognition of facies, bounding surfaces, and stratigraphic patterns in foreland ramp successions: an example from the Upper Devonian, Appalachian Basin,

399 Chadwick, G.H., 1919. Portage stratigraphy in western New York. Geological Society of $400 \quad$ America Bulletin 30, 157.

401 Chadwick, G.H., 1923. Chemung stratigraphy in western New York. Geological Society of America Bulletin 34, 68-69.

403 Chadwick, G.H., 1924. The stratigraphy of the Chemung Group in western New York. New 404 York State Museum Bulletin 251, 18 ${ }^{\text {th }}$ Report of the Director, 1922: 149-157.

405 Chadwick, G.H., 1935. Chemung is Portage. Geological Society of America Bulletin 46, 343$406 \quad 354$.

407 Christie, M., Holland S.M., Bush, A.M., 2013. Contrasting the ecological and taxonomic $408 \quad$ consequences of extinction. Paleobiology 39, 538-559. 
Clarke, J.M., 1899. The Naples fauna (fauna with Manticoceras intumescens) in western New

$410 \quad$ York. Annual Report of State Geologist for the year 1896, $50^{\text {th }}$ Annual Report of the

$411 \quad$ Regents, 2:29-161.

412 Clarke, J.M., Luther, D. D., 1908. Geologic map and descriptions of the Portage and Nunda

413 quadrangles, including a map of Letchworth Park. New York State Museum Bulletin 118,

$414 \quad$ Paleontology 18.

415 Clarke, J.M., Swartz, C.K., 1913a. Middle and Upper Devonian Text. Maryland Geological

416 Survey, Johns Hopkins Press, Baltimore.

417 Clarke, J.M., Swartz, C.K., 1913b. Devonian Plates. Maryland Geological Survey, Johns

418 Hopkins Press, Baltimore.

419 Cooper, G.A., Dutro, J.T., Jr., 1982. Devonian brachiopods of New Mexico. Bulletins of $420 \quad$ American Paleontology 82-83.

421 Copper, P., 1998. Evaluating the Frasnian-Famennian mass extinction: comparing brachiopod 422 faunas. Acta Palaeontologica Polonica 43, 137-154.

423 Copper, P., 2002. Reef development at the Frasnian/Famennian mass extinction boundary.

424 Palaeogeography, Palaeoclimatology, Palaeoecology 181, 27-65.

425 Day, J., 1998. Distribution of latest Givetian-Frasnian Atrypida (Brachiopoda) in central and 426 western North America. Acta Palaeontologica Polonica 43, 205-240.

427 Day, J., 2010. Subtropical record of Upper Devonian (late Frasnian-early Famennian) sea level 428 events and Kellwasser extinction bioevents, Southern Ouachita Margin-Western 429 Laurussia (Arizona-New Mexico, Central and Northern Mexico). Geological Society of $430 \quad$ America Abstracts with Programs 42(2), 89. 
431 Day, J., Copper, P., 1998. Revision of latest Givetian-Frasnian Atrypida (Brachiopoda) from

432 central North America. Acta Palaeontologica Polonica 43, 155-204.

433 Day, J., Over, D.J., 2002. Post-extinction survivor fauna from the lowermost Famennian of

434 eastern North America. Acta Palaeontologica Polonica 47, 189-202.

435 Dutro, J.T., 1981. Devonian brachiopod biostratigraphy of New York State, in: Oliver, W.A.,

436 Klapper, G. (Eds.), Devonian Biostratigraphy of New York, Part 1. International Union

437 of Geological Sciences, Subcommission on Devonian Stratigraphy, Washington, D.C., pp.

$438 \quad 67-82$.

439 Empire State Oil and Gas Information System, accessed in 2013. http://esogis.nysm.nysed.gov.

$440 \quad$ Reservoir Characterization Group, New York State Museum.

441 Filer, J.K., 2002. Late Frasnian sedimentation cycles in the Appalachian basin—possible

442 evidence for high frequency eustatic sea-level changes. Sedimentary Geology 142, 31-52.

443 Filer, J.K., 2003. Stratigraphic evidence for a Late Devonian possible back-bulge basin in the

$444 \quad$ Appalachian Basin, United States. Basin Research 15, 417-429.

445 Greiner, H., 1957. "Spirifer disjunctus": its evolution and paleoecology in the Catskill Delta.

446 Peabody Museum of Natural History, Yale University, Bulletin 11.

447 Hall, J., 1867. Containing descriptions and figures of the fossil Brachiopoda of the upper

448 Helderberg, Hamilton, Portage and Chemung Groups. Natural History of New York,

449 Palaeontology IV(I). Geological Survey of New York, Albany, New York.

450 Hall, J., Clarke, J.C., 1892. An introduction to the study of the genera of Palaeozoic Brachiopoda,

451 Part I. Natural History of New York, Palaeontology VIII. Geological Survey of New

$452 \quad$ York, Albany, New York. 
453 Hall, J., Clarke, J.C., 1894. An introduction to the study of the genera of Palaeozoic Brachiopoda,

454 Part II. Natural History of New York, Palaeontology VIII. Geological Survey of New $455 \quad$ York, Albany.

456 Hall, J., Whitney, J.D., 1858. Report on the Geological Survey of the State of Iowa, embracing 457 the results of investigations made during portions of the years 1855, 56, \& 57: Part II:

458 Palaeontology. Report on the Geological Survey of the State of Iowa 1.

459 House, M.R., 2002. Strength, timing, setting and cause of mid-Palaeozoic extinctions.

460 Palaeogeography, Palaeoclimatology, Palaeoecology 181, 5-25.

461 Joachimski, M.M., Buggisch, W., 1993. Anoxic events in the late Frasnian —causes of the $462 \quad$ Frasnian-Famennian faunal crisis? Geology 21, 675-678.

463 Klapper, G., 1989. The Montagne Noire Frasnian (Upper Devonian) conodont succession, in: 464 McMillan, N.J., Embry, A.F., Glass, D.J. (Eds.), Devonian of the World. Canadian 465 Society of Petrolroleum Geologists Memoir 14, pp. 449-468.

466 Klapper, G., 1997. Graphic correlation of Frasnian (Upper Devonian) sequences in Montagne 467 Noire, France, and western Canada. Geological Society of America Special Paper 321, $468 \quad 113-129$.

469 Klapper, G., Feist, R., Becker, R.T., House, M.R., 1994. Definition of the Frasnian/Famennian $470 \quad$ Stage boundary. Episodes 16, 433-441.

471 Linsley, D.M. 1994. Devonian Paleontology of New York. Paleontology Research Institution $472 \quad$ Special Publication 21.

473 McClung, W.S., Eriksson, K.A., Terry, D.O., Jr., Cuffey, C.A., 2013. Sequence stratigraphic 474 hierarchy of the Upper Devonian Foreknobs Formation, central Appalachian Basin, USA: 
Evidence for transitional greenhouse to icehouse conditions. Palaeogeography, Palaeoclimatology, Palaeoecology 387, 104-125.

477 McGhee, G.R., Jr., 1976. Late Devonian benthic marine communities of the central Appalachian 478 Allegheny Front. Lethaia 9, 111-136.

479 McGhee, G.R., Jr., 1977, The Frasnian-Famennian (Late Devonian) boundary within the 480 Foreknobs Formation, Maryland and West Virginia, Geological Society of America $481 \quad$ Bulletin 88, 806-808.

482 McGhee, G.R., Jr., 1996. The Late Devonian Mass Extinction: The Frasnian/Famennian Crisis. 483 Columbia University Press, New York.

484 McGhee, G.R., Jr., 2013. When the Invasion of Land Failed: the Legacy of the Devonian 485 Extinctions. Columbia University Press, New York.

486 McGhee, G.R., Jr., Dennison, J.M., 1980. Late Devonian chronostratigraphic correlations 487 between the central Allegheny Front and central and western New York. Southeastern 488 Geology 21, 279-286.

489 McGhee, G.R., Jr., Sutton, R.G., 1981. Late Devonian marine ecology and zoogeography of the 490 central Appalachians and New York. Lethaia 14, 27-43.

491 McGhee, G.R., Jr., Sutton, R.G., 1983. Evolution of late Frasnian (Late Devonian) marine 492 environments in New York and the central Appalachians. Alcheringa 7, 9-21.

493 McGhee, G.R., Jr., Sutton, R.G., 1985. Late Devonian marine ecosystems of the lower West 494 Falls Group in New York, in: Woodrow, J.W., Sevon, W.D. (Eds.), The Catskill Delta. 495 Geological Society of America Special Paper 201, pp. 199-209. 
McGhee, G.R., Jr., Sheehan, P.M., Bottjer, D.J., Droser, M.L., 2004. Ecological ranking of Phanerozoic biodiversity crises: ecological and taxonomic severities are decoupled. Palaeogeography, Palaeoclimatology, Palaeoecology 211, 289-297.

Murphy, A.E., Sageman, B.B., Hollander, D.J., 2000. Eutrophication by decoupling of the marine biogeochemical cycles of $\mathrm{C}, \mathrm{N}$, and P: a mechanism for the Late Devonian mass

Oliver, W.A., Sorauf, J.E., 1981. Rugose coral biostratigraphy of the Devonian of New York and adjacent areas, in: Oliver, W.A., Klapper, G. (Eds.), Devonian Biostratigraphy of New York, Part 1. International Union of Geological Sciences, Subcommission on Devonian extinction. Geology 28, 427-430. Stratigraphy, Washington, D.C., pp. 97-105.

Oliver, W.A., Sorauf, J.E., 1983. Devonian rugose corals of New York, in: Sorauf, J.E., Oliver,

516 Over, D.J., 2007. Conodont biostratigraphy of the Chattanooga Shale, Middle and Upper

517 Devonian, southern Appalachian Basin, eastern United States. Journal of Paleontology 81, 518 $1194-1217$. 
519 Pepper, J.F. 1954. Bedrock geology of the Hornell quadrangle, New York. USGS Geologic

$520 \quad$ Quadrangle Map GQ 37.

521 Pepper, J.F., deWitt, W., 1950, Stratigraphy of the Upper Devonian Wiscoy Sandstone and the

522 equivalent Hanover Shale in western and central New York. USGS Oil and Gas

$523 \quad$ Investigations Chart OC 37.

524 Pepper, J.F., deWitt, W., 1951, Stratigraphy of the Late Devonian Perrysburg Formation in

525 western and west-central New York. USGS Oil and Gas Investigations Chart OC 45.

526 Pepper, J.F., deWitt, W., Colton, G.W., 1956, Stratigraphy of the West Falls Formation of Late

527 Devonian age in western and west-central New York. USGS Oil and Gas Investigations $528 \quad$ Chart OC 55.

529 Rickard, L.V., 1964. Correlation of the Devonian rocks in New York State. New York State $530 \quad$ Museum Map and Chart Series 4.

531 Rickard, L.V., 1975. Correlations of the Silurian and Devonian Rocks in New York State. New

$532 \quad$ York Museum and Science Service Map and Chart Series 24.

533 Rickard, L.V., Fisher, D.W., 1970. Geologic Map of New York: Finger Lakes Sheet and Niagara

$534 \quad$ Sheet. New York State Museum and Science Service Map and Chart Series 15.

535 Rode, A.L., Lieberman, B.S., 2004. Using GIS to unlock the interactions between biogeography,

536 environment, and evolution in Middle and Late Devonian brachiopods and bivalves.

537 Palaeogeography, Palaeoclimatology, Palaeogeography 211, 345-359.

538 Roe, L. M., II., 1975. Sedimentary environments of the Java Group (Upper Devonian) - a three

539 dimensional study. Unpublished Ph.D. Dissertation, University of Rochester, Rochester, $540 \quad$ New York. 
541 Roen, J.B., deWitt, W., 1984. Stratigraphic framework of the Devonian black shales of the

542 Appalachian Basin. Untied States Department of the Interior, Geological Survey, Open-

$543 \quad$ File Report 84-111.

544 Rong, J.Y., Cocks, L.R.M., 1994. True Strophomena and a revision of the classification and 545 evolution of strophomenoid and 'strophodontoid' brachiopods. Palaeontology 37, 651$546 \quad 694$.

547 Rossbach, T.J., 1992. Biostratigraphy of the Greenland Gap Group in Virginia and West Virginia.

$548 \quad$ Unpublished Ph.D. Dissertation, University of North Carolina, Chapel Hill, North

$549 \quad$ Carolina.

550 Sallan, L.C., Coates, M.I., 2010. End-Devonian extinction and a bottleneck in the early evolution 551 of modern jawed vertebrates. Proceedings of the National Academy of Sciences USA 107, $552 \quad 10131-10135$.

553 Schindler, E., 1993. Event-stratigraphic markers within the Kellwasser Crisis near the

554 Frasnian/Famennian boundary (Upper Devonian) in Germany. Palaeogeography, $555 \quad$ Palaeoclimatology, Palaeoecology 104, 115-125.

556 Smith, G.J., Jacobi, R.D., 2000. Re-evaluating the Canadaway Group: a revised stratigraphic 557 correlation chart for the Upper Devonian of southwestern New York State. Northeastern $558 \quad$ Geology and Environmental Sciences 22, 173-201.

559 Smith, G.J., Jacobi, R.D., 2001. Tectonic and eustatic signals in the sequence stratigraphy of the 560 Upper Devonian Canadaway Group, New York State. AAPG Bulletin 85, 325-357.

561 Smith, G.J., Jacobi, R.D., 2006. Depositional and tectonic models for Upper Devonian

562 sandstones in western New York State. New York State Geological Association 563 Guidebook 78, 54-115. 
564 Sorauf, J.E., 1978. Upper Devonian Pachyphyllum (rugose coral) from New York State. Journal 565 of Paleontology 52, 818-829.

566 Sorauf, J.E., 1987. Upper Devonian (Frasnian) rugose corals from New York State. Journal of $567 \quad$ Paleontology 61, 676-689.

568 Sorauf, J.E., Pedder, A.E.H., 1986. Late Devonian rugose corals and the Frasnian-Famennian 569 crisis. Canadian Journal of Earth Sciences 23, 1265-1287.

570 Stainbrook, M.A., 1940. Orthoid brachiopods of the Cedar Valley Limestone of Iowa. American $571 \quad$ Midland Naturalist 23, 482-492.

572 Stainbrook, M.A., 1942. Brachiopoda from the High Point Sandstone of New York. American $573 \quad$ Journal of Science 42, 604-619.

574 Stainbrook, M.A., 1945. Brachiopoda of the Independence Shale of Iowa. Geological Society of $575 \quad$ America Memoirs 14, 1-68.

576 Stigall Rode, A.L., 2005. Systematic revision of the Middle and Late Devonian brachiopods

577 Schizophoria (Schizophoria) and 'Schuchertella' from North America. Journal of $578 \quad$ Systematic Palaeontology 3, 133-167.

579 Stigall Rode, A.L., Lieberman, B.S., 2005. Using environmental niche modeling to study the 580 Late Devonian biodiversity crisis, in: Over, D.J., Morrow, J.R., and Wignall, P.B. (Eds.), $581 \quad$ Understanding Late Devonian and Permian-Triassic Biotic and Climatic Events: Towards 582 an Integrated Approach. Elsevier, Amsterdam, pp. 93-180.

583 Stumm, E.C., 1960. New rugose corals from the Middle and Upper Devonian of New York.

$584 \quad$ Journal of Paleontology 34, 161-163.

585 Sutton, R.G., and McGhee, G.R., Jr., 1985. The evolution of Frasnian marine "community-types" 586 of south-central New York. Geological Society of America Special Papers 201, 211-224. 
587 Van Tassell, J. 1987. Upper Devonian Catskill Delta margin cyclic sedimentation: Brallier,

588 Scherr, and Foreknobs Formations of Virginia and West Virginia. Geological Society of

$589 \quad$ America Bulletin 99, 414-426.

590 Ver Straeten, C.A. 2009. The classic Devonian of the Catskill Front: a foreland basin record of 591 Acadian orogenesis. New York State Geological Association Guidebook 81, 7-1-7-54.

592 Warne, A.G., McGhee, G.R., Jr., 1991. Stratigraphic subdivisions of the Upper Devonian Scherr, 593 Foreknobs, and Lock Haven formations near the Allegheny Front of central Pennsylvania. $594 \quad$ Northeastern Geology 13, 96-109.

595 Williams, A., 1953. North American and European stropheodontids: their morphology and 596 systematics. Geological Society of America Memoir 56, 1-78.

597 Williams, H.S., 1908. The Dalmanellas of the Chemung Formation and a closely related new 598 brachiopod genus Thiemella. Proceedings of the United States National Museum, 18, 35$599 \quad 64$.

600 Woodrow, J.W., Sevon, W.D., eds. 1985. The Catskill Delta. Geological Society of America $601 \quad$ Special Paper 201.

602 Ziegler, W., 1962. Taxonomie und Phylogenie oberdevonischer Conodonten und ihre 603 stratigraphische Bedeutung. Abhandlungen des Hessischen Landesamtes für $604 \quad$ Bodenforschung 38, 1-166.

605 Ziegler, W., Sandberg, C.A., 1990. The Late Devonian standard conodont zonation. Courier $606 \quad$ Forschungsinstitut Senckenberg 121, 1-115. 


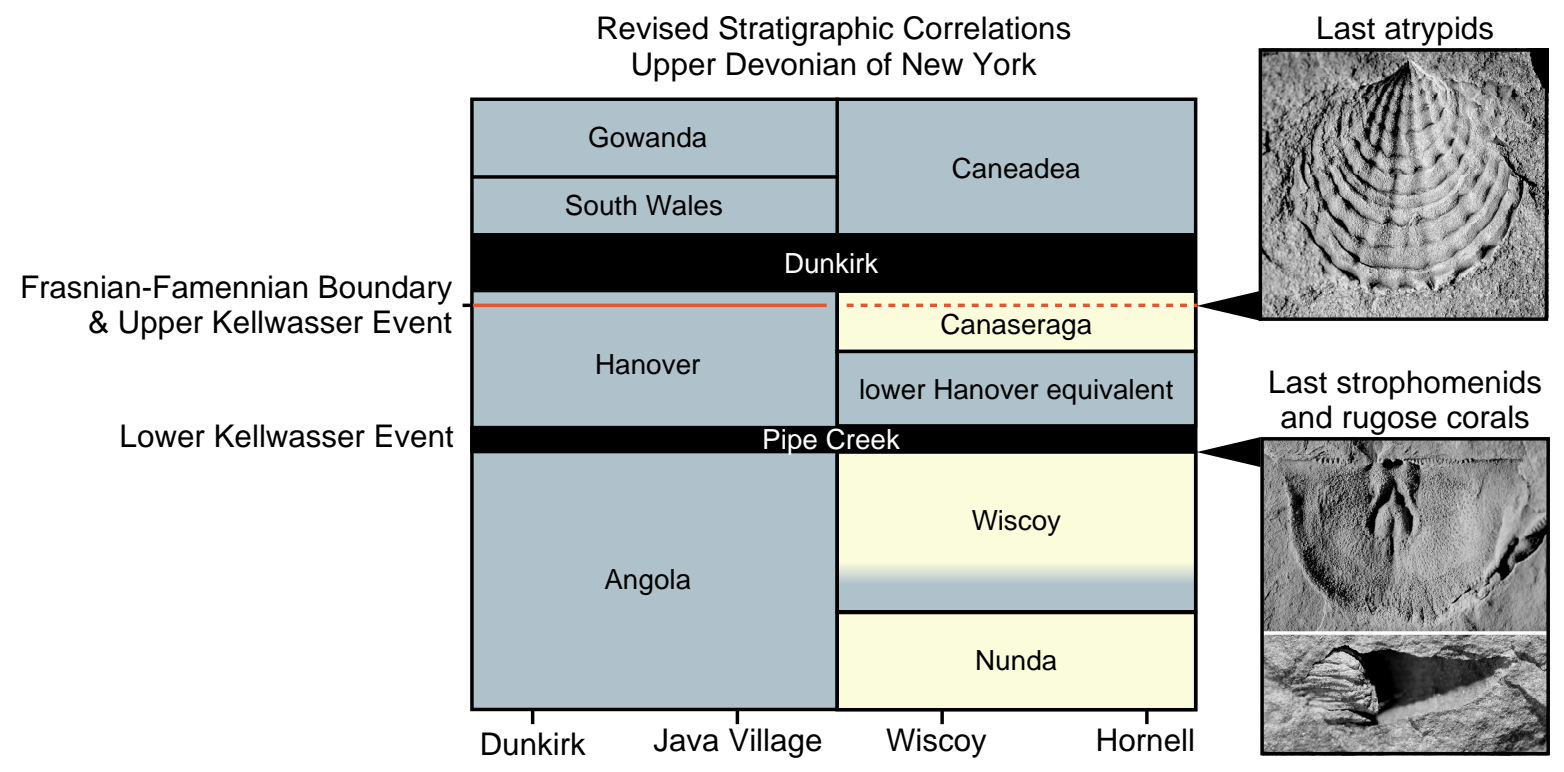




\section{Table Captions}

Table 1. Locality information for stratigraphic sections and wells. See Fig. 1 for map.

Table 2. Localities sampled for faunal data, with the occurrences of biostratigraphically informative species of strophomenid, orthid, atrypid, athyrid, and selected spriferid and spiriferinid brachiopods. Rugose corals are indicated but not identified. See Fig. 1 for map. The ranges of most taxa shown here are also shown in Fig. 5. Cyrtospiriferid brachiopods were generally not included in this study pending further study; however, two Famennian species are included in this table because they are easily recognized and are among the first new taxa to appear in the Famennian. 
Table 1

\begin{tabular}{|c|c|c|c|c|}
\hline Site & Name & Latitude $\mathbf{N}$ & Longitude W & Source \\
\hline \multicolumn{5}{|c|}{ Primary sections (faunal data shown in Fig. 4) } \\
\hline TGB & Tioga, PA, Rt. 287 & $41^{\circ} 54.423^{\prime}$ & $77^{\circ} 09.715^{\prime}$ & Bush et al., this paper \\
\hline CAM & Cameron & $42^{\circ} 12.008^{\prime}$ & $77^{\circ} 26.219^{\prime}$ & Bush et al., this paper \\
\hline $\mathrm{BCP}$ & Big Creek & $42^{\circ} 21.810^{\prime}$ & $77^{\circ} 38.675^{\prime}$ & Bush et al., this paper \\
\hline \multicolumn{5}{|c|}{ Additional sections } \\
\hline TGA & Tioga, PA, Rt. 15 & $41^{\circ} 54.690^{\prime}$ & $77^{\circ} 07.446^{\prime}$ & Bush et al., this paper \\
\hline ERC & Ells Road Creek & $42^{\circ} 15.303^{\prime}$ & $77^{\circ} 40.773^{\prime}$ & $\begin{array}{l}\text { Bush et al., this paper; Pepper and } \\
\text { deWitt unpublished }\end{array}$ \\
\hline LET & Letchworth Park & $42^{\circ} 35.15^{\prime}$ & $78^{\circ} 01.13^{\prime}$ & Pepper et al., 1956 \\
\hline WSC & Wiscoy Creek & $42^{\circ} 30.280^{\prime}$ & $78^{\circ} 5.014^{\prime}$ & Smith and Jacobi, 2001 \\
\hline MIL & Mills-Mills & $42^{\circ} 30.050^{\prime}$ & $78^{\circ} 7.218^{\prime}$ & Smith and Jacobi, 2001 \\
\hline JFL & Johnson's Falls & $42^{\circ} 43.75^{\prime}$ & $78^{\circ} 27.17^{\prime}$ & Pepper et al., 1956 \\
\hline JAV & Java Village & $42^{\circ} 40.33^{\prime}$ & $78^{\circ} 26.08^{\prime}$ & Pepper and deWitt, 1950, 1951 \\
\hline HOL & Holland & $42^{\circ} 42.25^{\prime}$ & $78^{\circ} 33.83^{\prime}$ & Pepper and deWitt, 1950, 1951 \\
\hline CAZ & Cazenovia Creek & $42^{\circ} 47.17^{\prime}$ & $78^{\circ} 41.25^{\prime}$ & Pepper et al., 1956 \\
\hline PIP & Pipe Creek & $42^{\circ} 41.75^{\prime}$ & $78^{\circ} 41.25^{\prime}$ & Pepper and deWitt, 1950, 1951 \\
\hline AGL & Alice Glen & $42^{\circ} 43.17^{\prime}$ & $78^{\circ} 45.00^{\prime}$ & Pepper and deWitt, 1950 \\
\hline IRG & Irish Gulf & $42^{\circ} 32.33^{\prime}$ & $78^{\circ} 45.25^{\prime}$ & Pepper and deWitt, 1950, 1951 \\
\hline WAL & Walnut Creek & $42^{\circ} 32.33^{\prime}$ & $79^{\circ} 10.08^{\prime}$ & Pepper and deWitt 1950, 1951 \\
\hline \multicolumn{5}{|c|}{ Well logs } \\
\hline SWL & Steuben Co. well log & $42^{\circ} 14.155^{\prime}$ & $77^{\circ} 30.764^{\prime}$ & $\begin{array}{l}\text { Empire State Oil and Gas } \\
\text { Information System, } 2013\end{array}$ \\
\hline EWL & Erie Co. well log & $42^{\circ} 32.495^{\prime}$ & $78^{\circ} 42.016^{\prime}$ & $\begin{array}{l}\text { Empire State Oil and Gas } \\
\text { Information System, } 2013\end{array}$ \\
\hline
\end{tabular}


Table 2

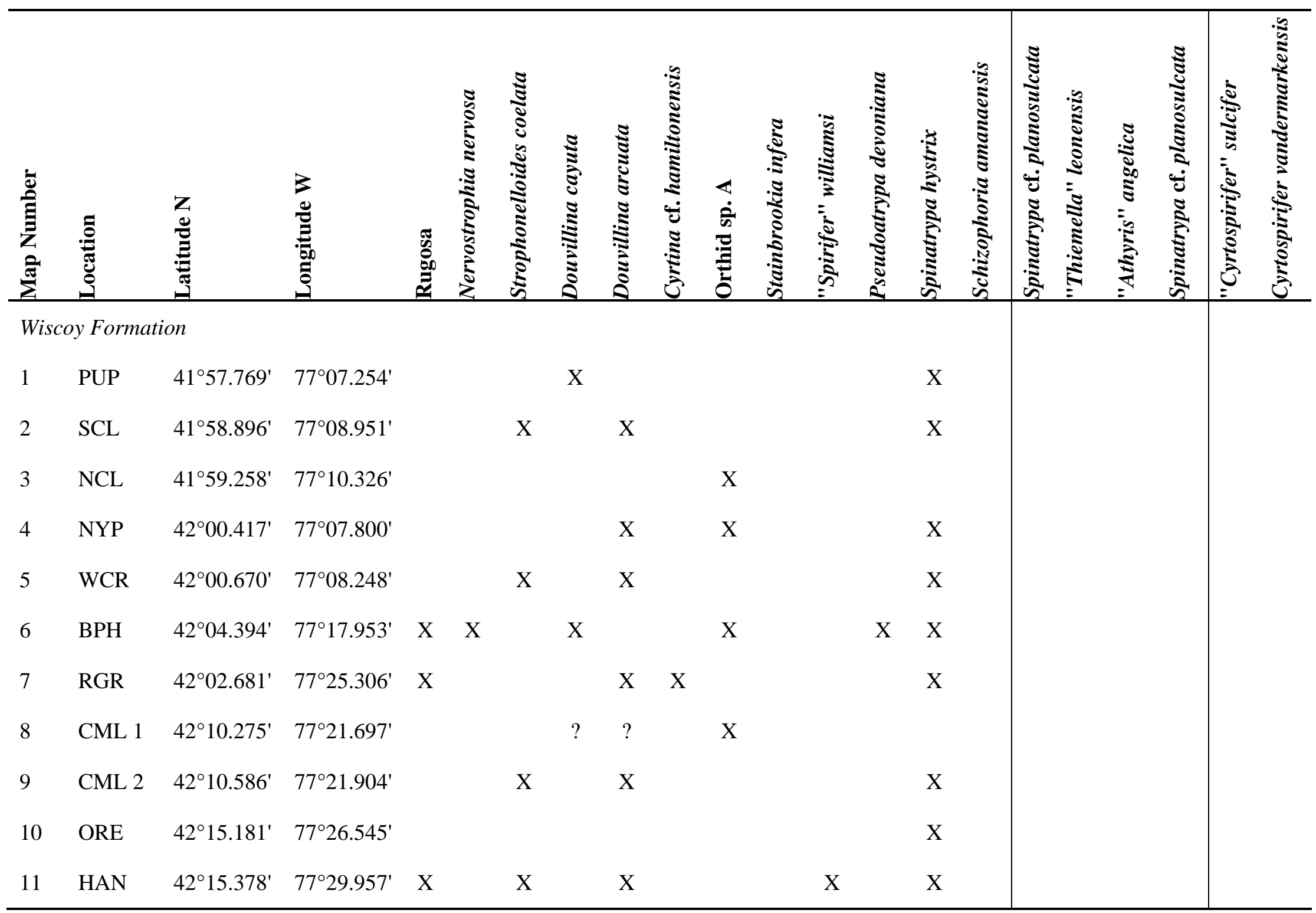




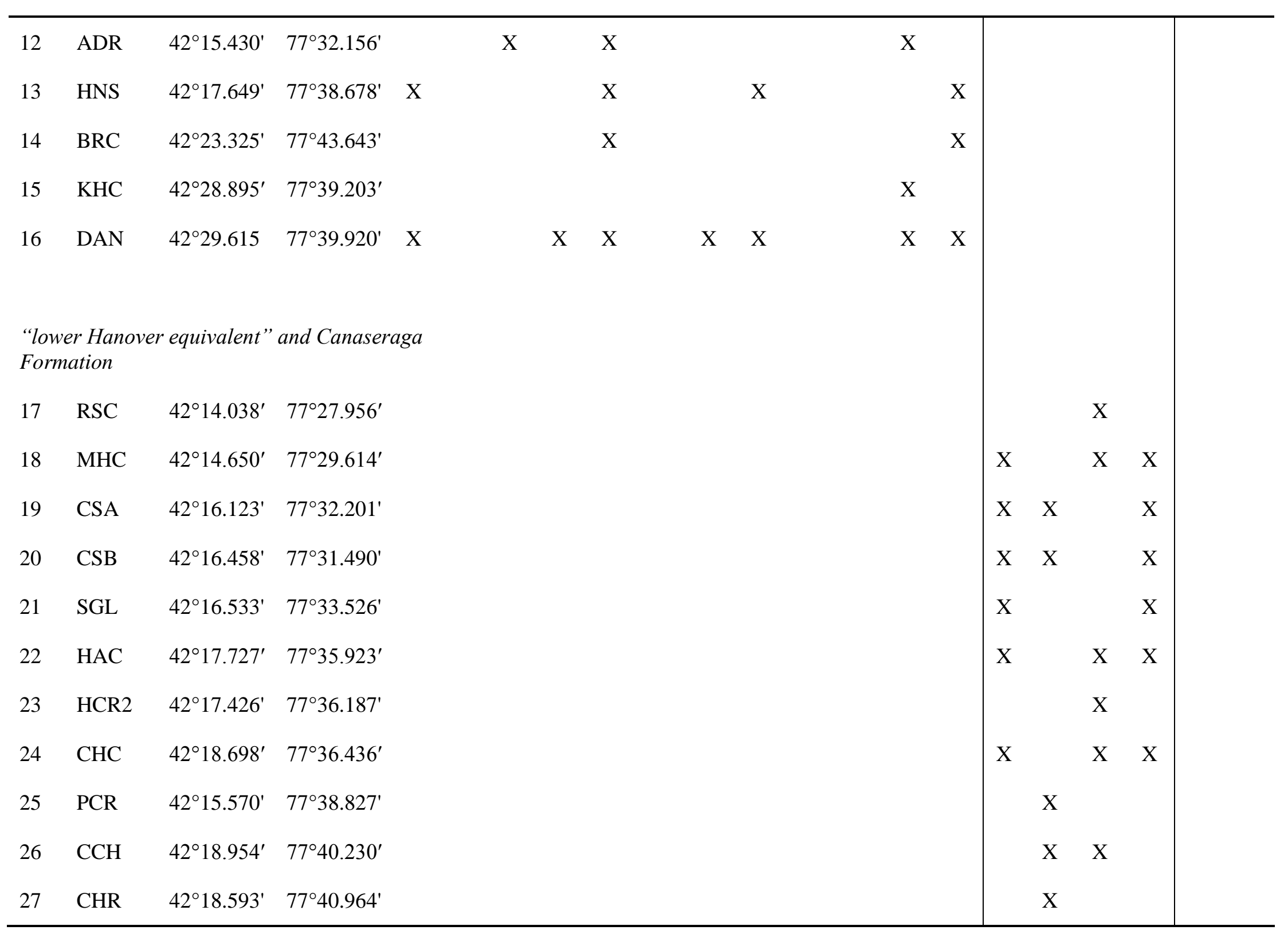




\begin{tabular}{|c|c|c|c|c|c|c|c|c|}
\hline 28 & MHV & $42^{\circ} 18.544^{\prime}$ & $77^{\circ} 45.203^{\prime}$ & & $\mathrm{X}$ & $\mathrm{X}$ & & \\
\hline 29 & SLD & $42^{\circ} 25.871^{\prime}$ & $77^{\circ} 46.985^{\prime}$ & $\mathrm{X}$ & $\mathrm{X}$ & $\mathrm{X}$ & $\mathrm{X}$ & \\
\hline 30 & SKI & $42^{\circ} 28.609^{\prime}$ & $77^{\circ} 51.441^{\prime}$ & $\mathrm{X}$ & & & $\mathrm{X}$ & \\
\hline $30 \mathrm{a}$ & EHR & $42^{\circ} 28.545^{\prime}$ & $77^{\circ} 50.612^{\prime}$ & & $\mathrm{X}$ & & & \\
\hline 31 & BLK & $42^{\circ} 15.391^{\prime}$ & $77^{\circ} 40.452^{\prime}$ & & $\mathrm{X}$ & $\mathrm{X}$ & & \\
\hline \multicolumn{9}{|c|}{ Dunkirk Formation and above } \\
\hline-- & TGA & $41^{\circ} 54.690^{\prime}$ & $77^{\circ} 07.446^{\prime}$ & & & $\mathrm{X}$ & & $?$ \\
\hline 32 & GRN & $42^{\circ} 01.439^{\prime}$ & $77^{\circ} 30.573^{\prime}$ & & & & & $\mathrm{X}$ \\
\hline 33 & BVS & $42^{\circ} 17.941^{\prime}$ & $77^{\circ} 30.952^{\prime}$ & & & & & \\
\hline-- & ERC & $42^{\circ} 15.303^{\prime}$ & $77^{\circ} 40.773^{\prime}$ & & & & & \\
\hline 34 & ELL & $42^{\circ} 16.237^{\prime}$ & $77^{\circ} 42.485$ & & & & & \\
\hline 35 & ALF & $42^{\circ} 15.507^{\prime}$ & $77^{\circ} 46.986^{\prime}$ & & & $\mathrm{X}$ & & $\mathrm{X}$ \\
\hline 36 & ALT & $42^{\circ} 15.338^{\prime}$ & $77^{\circ} 47.102^{\prime}$ & & & $\mathrm{X}$ & & $\mathrm{X}$ \\
\hline 37 & SHE & $42^{\circ} 16.784^{\prime}$ & $77^{\circ} 46.110^{\prime}$ & & & $X$ & & $\mathrm{X}$ \\
\hline 38 & MHV2 & $42^{\circ} 17.682^{\prime}$ & $77^{\circ} 46.628^{\prime}$ & & & $X$ & & $X$ \\
\hline 39 & BRN & $42^{\circ} 23.209^{\prime}$ & $77^{\circ} 47.982^{\prime}$ & & & & & \\
\hline 40 & SHR & $42^{\circ} 30.148^{\prime}$ & $77^{\circ} 47.496^{\prime}$ & & & & & \\
\hline
\end{tabular}




\begin{tabular}{lll|l|l}
\hline- & MIL & $42^{\circ} 30.050^{\prime}$ & $78^{\circ} 07.218^{\prime}$ & \\
41 & WHC & $42^{\circ} 19.311^{\prime}$ & $78^{\circ} 06.416^{\prime}$ & \\
42 & GHC & $42^{\circ} 18.285^{\prime}$ & $78^{\circ} 50.614^{\prime}$ & $X$ \\
\hline
\end{tabular}




\section{Figure Captions}

Fig. 1. Locality maps. A) Eastern United States with the field area in New York and Pennsylvania highlighted. B) Expanded view of the highlighted region from panel A. In western New York, the Java Group is marked in black. The base of the group (northern boundary) is defined by the Angola-Pipe Creek contact (LK equivalent). The top of the group (southern boundary) is marked by the Hanover-Dunkirk contact, which is slightly above the UK equivalent (Over, 1997). In the eastern end of the outcrop belt, the contact between the Wiscoy and the overlying shale is marked; previously, this contact was correlated with the Hanover-Dunkirk contact in the west, but we correlate it with the Angola-Pipe Creek contact. C) Detailed geologic map of the region highlighted in panel B. Stratigraphic assignments reflect the new correlations proposed here. Sampling locations and abbreviations are listed in Tables 1 and 2. The "primary measured sections" (BCP, CAM, and TGB) were sampled bed-by-bed for fossils, and the "other measured sections” are discussed or figured but not necessarily sampled intensively for fossils. “Other outcrops” were sampled for fossils but the sections were not measured. Geologic maps based on Pepper and deWitt (1950), Pepper (1954), and Rickard and Fisher (1970).

Fig. 2. Correlations between the western and eastern portions of the outcrop belt. A) Chadwick (1923, 1935). B) Pepper and deWitt (1950, 1951), Rickard (1964), Rickard and Fisher (1970), and Smith and Jacobi (2000, 2001). C) Rickard (1975) and Roe (1975). D) Revised correlations proposed here. Panels A, B, and C are composites of similar (though not necessarily identical) correlations from multiple sources. F-F: Frasnian-Famennian boundary. UK: Upper Kellwasser equivalent. LK: Lower Kellwasser equivalent. 
Fig. 3. Outcrop photographs in descending stratigraphic order. A) Caneadea Formation, location ERC (creek west of Ells Road near intersection with Purdy Creek Road, south of Hornell, NY). B) Canaseraga Formation, location 20 (CSB, Campbell Creek Road east of Canisteo, NY). C) Pipe Creek Shale (outlined unit) and adjacent strata, 9-19 m at section TGB (Rt. 287, Tioga, PA). The Pipe Creek is $4.4 \mathrm{~m}$ thick. D) Upper Wiscoy Formation, 5.0-7.5 $\mathrm{m}$ at section TGB. Staff ruled in 20-cm increments. See Fig. 1 for map and Tables 1 and 2 for further locality information.

Fig. 4. Stratigraphic distribution of key fossil taxa in the upper Wiscoy Formation and overlying strata. A) Big Creek, Hornell, NY (BCP). B) Cameron, NY (CAM). C) Rt. 287, Tioga, PA (TGB). See Fig. 1 and Table 1 for locations. Height in meters. Ranges include strophomenid, orthid, atrypid, athyrid, and selected spriferid and spiriferinid brachiopods that first or last occurred in these sections; long-ranging taxa that span the entire stratigraphic interval are excluded for clarity. The distribution of rugose corals is also shown.

Fig. 5. Brachiopods from the F-F boundary interval of New York. A) Nervostrophia nervosa, mold, location 6 (BPH). B) Strophonelloides coelata, interior mold, ventral valve, sample TGB 5. C) Douvillina arcuata, interior mold, ventral valve, sample BCP 106. D) Douvillina arcuata, interior mold, dorsal valve, sample CAM 43. E) Spinatrypa hystrix, exterior mold, location 12 (ADR). F) Spinatrypa cf. planosulcata, exterior mold, sample CAM 134. G) Schizophoria amanaensis, interior mold, dorsal valve, sample BCP 134. H-I) Schizophoria amanaensis, ventral and anterior views, location 13 (HNS). J-L) Stainbrookia infera, ventral, dorsal, and 
anterior views, location 13 (HNS). M) Orthid sp. A, interior mold, dorsal valve, sample BCP 53. N-O) Orthid sp. A, exterior and interior molds, ventral valve, sample CAM 23. P) "Thiemella" leonensis, exterior mold, location 25 (PCR). Q) “Thiemella” leonensis, interior mold, dorsal valve, location BCP, float. R) “Thiemella” leonensis, interior mold, ventral valve, sample CAM 132. Specimens were coated with ammonium chloride and are shown at the same scale.

Fig. 6. Summary of stratigraphic ranges of selected biostratigraphically important brachiopods in the upper Frasnian-lower Famennian of New York. F-F: Frasnian-Famennian boundary. UK: Upper Kellwasser equivalent. LK: Lower Kellwasser equivalent.

Fig. 7. Conodonts from the F-F boundary interval of New York. A) Palmatolepis winchelli, sample BCP 140 (see Fig. 4A). C) Ancyrognathus symmetricus, "Hume” Shale (equivalent to the Dunkirk Formation; Fig. 2D), location MIL in Fig. 1 (Mills-Mills, NY).

Fig. 8. Stratigraphic sections from the F-F boundary interval in New York and northern Pennsylvania showing the correlations proposed here (i.e., the shale above the Wiscoy correlates with the Pipe Creek, not the Dunkirk; Fig. 2D). Data from Pepper and DeWitt $(1950,1951)$, Pepper et al. (1956), Over (1997), Smith and Jacobi (2001), and our own field work. The exact position of the F-F boundary in the eastern part of the outcrop belt is not well constrained. See Fig. 1 and Table 1 for locations and sources of data. F-F: Frasnian-Famennian boundary. UK: Upper Kellwasser equivalent. LK: Lower Kellwasser equivalent. 
Fig. 9. Subsurface data. A) Gamma-ray log from Erie County well 21136 (see Fig. 2 of Filer, 2002). Numbers 7-11 correspond with Filer’s (2002) transgressive-regressive cycles. B) Gammaray log from Steuben County well 12145. C) Lithologic log from CAM outcrop (Cameron, NY; see Fig. 4B). D) Gamma-ray log from Tioga, PA outcrops (TGB, lower, and TGA, upper). Data from Castle (2000). E) Lithologic logs of Tioga outcrops (see Fig. 4C). PC: Pipe Creek. UK: Upper Kellwasser equivalent. LK: Lower Kellwasser equivalent. Subsurface gamma-ray logs downloaded from the Empire State Oil and Gas Information System (2013). 
Figure 1

2 column
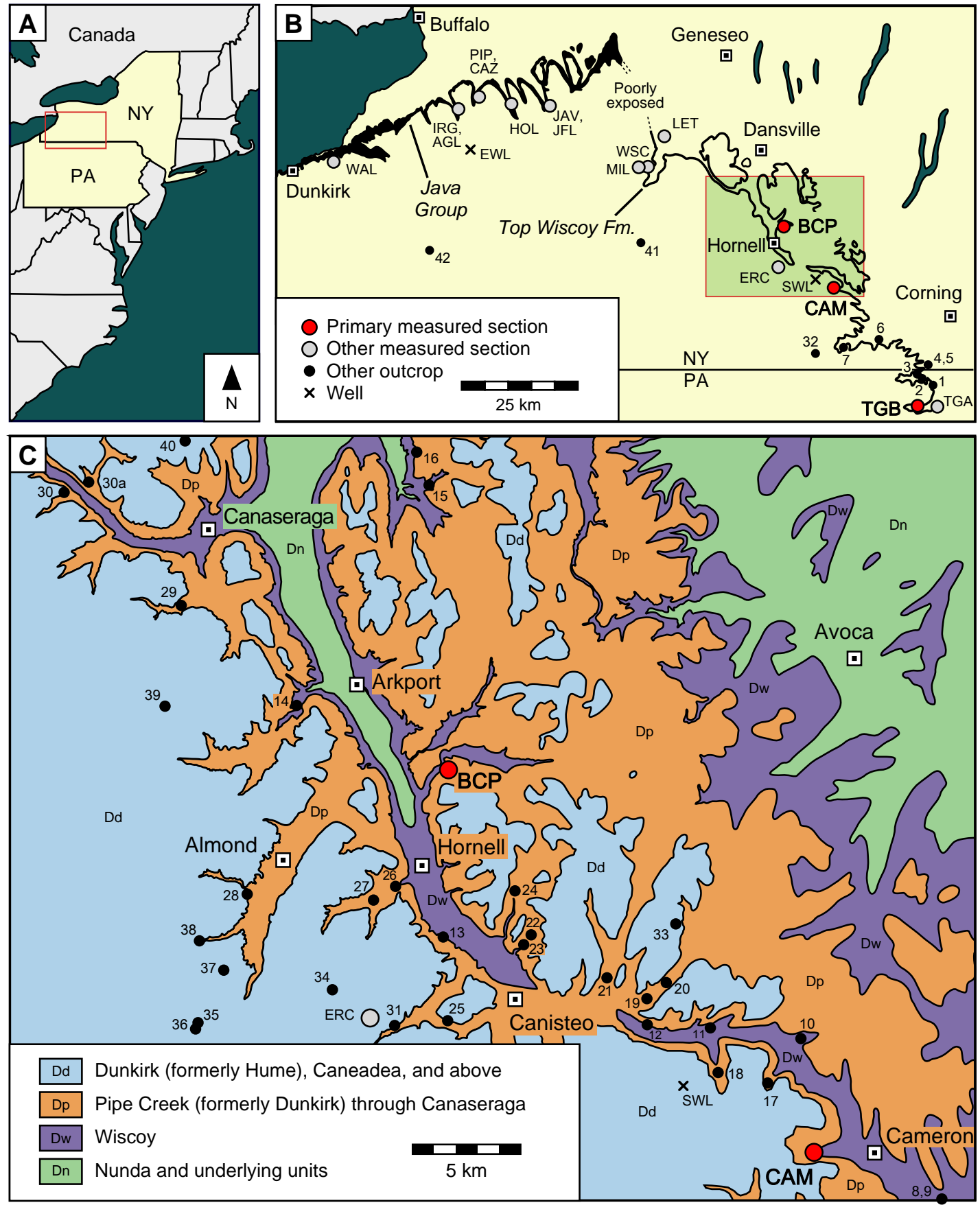
Figure 2

2 column

A. Chadwick (1923, 1935)

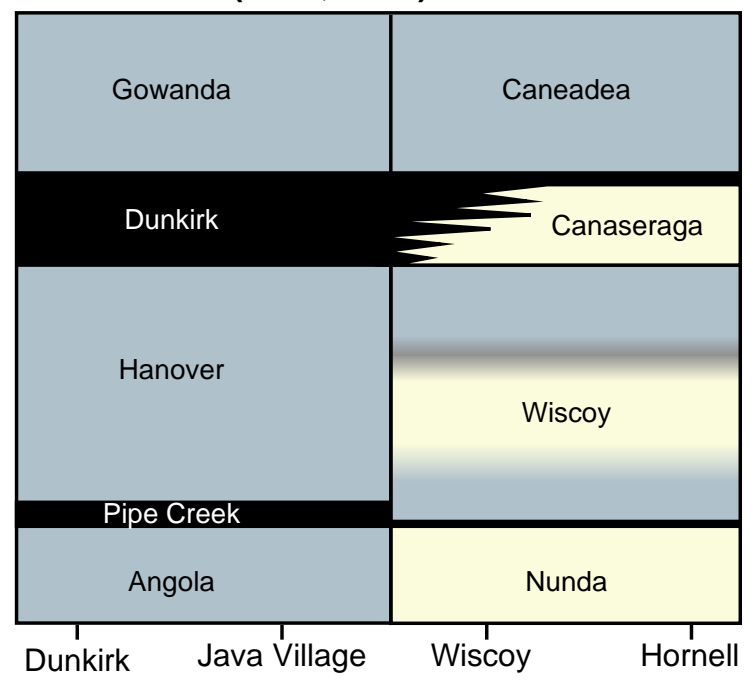

C. Rickard (1975), Roe (1975)

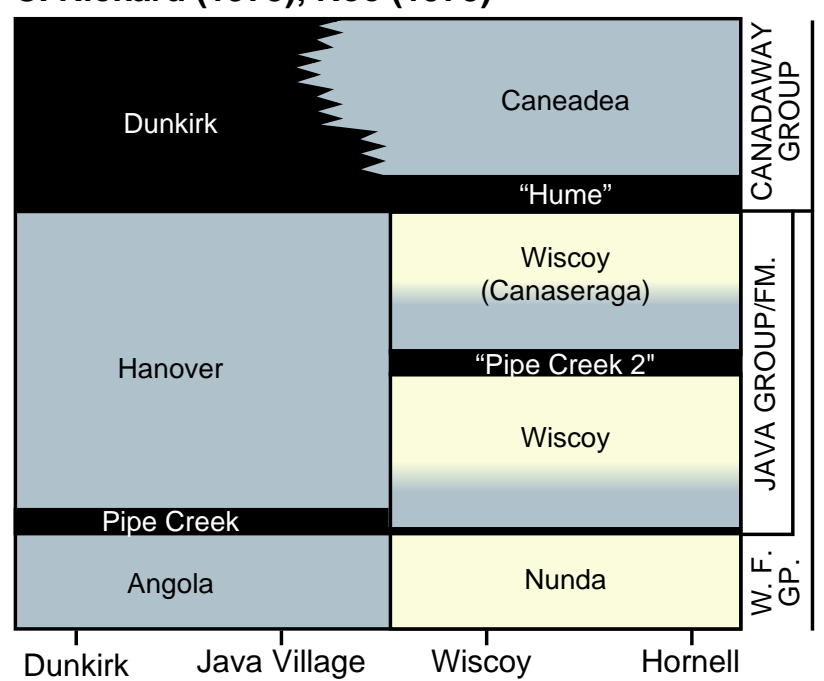

Black/Dark Shale
B. Pepper and deWitt $(1950,1951)$, Rickard (1964), Smith and Jacobi (2000)

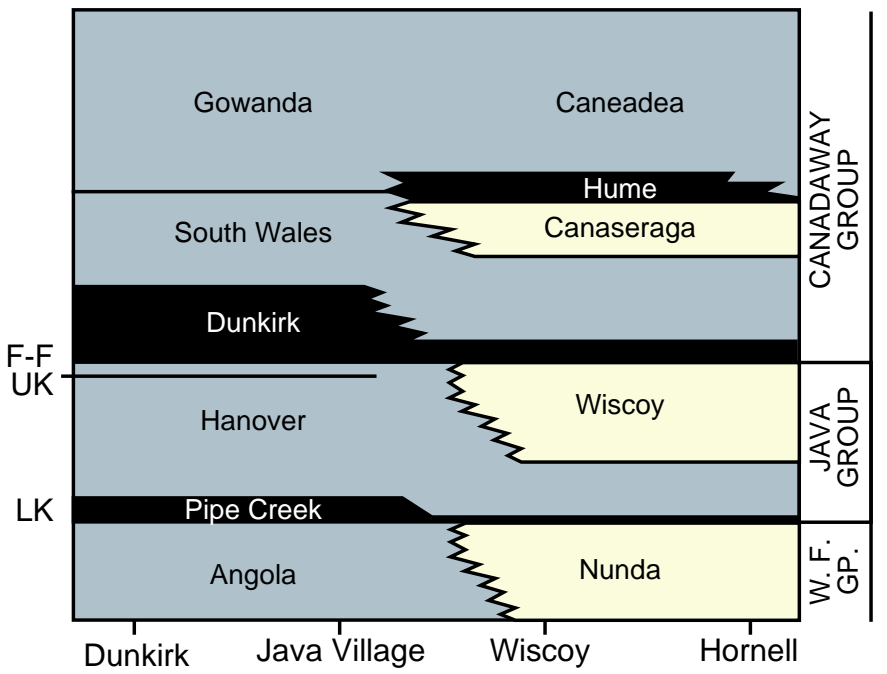

\section{Revised Correlations}

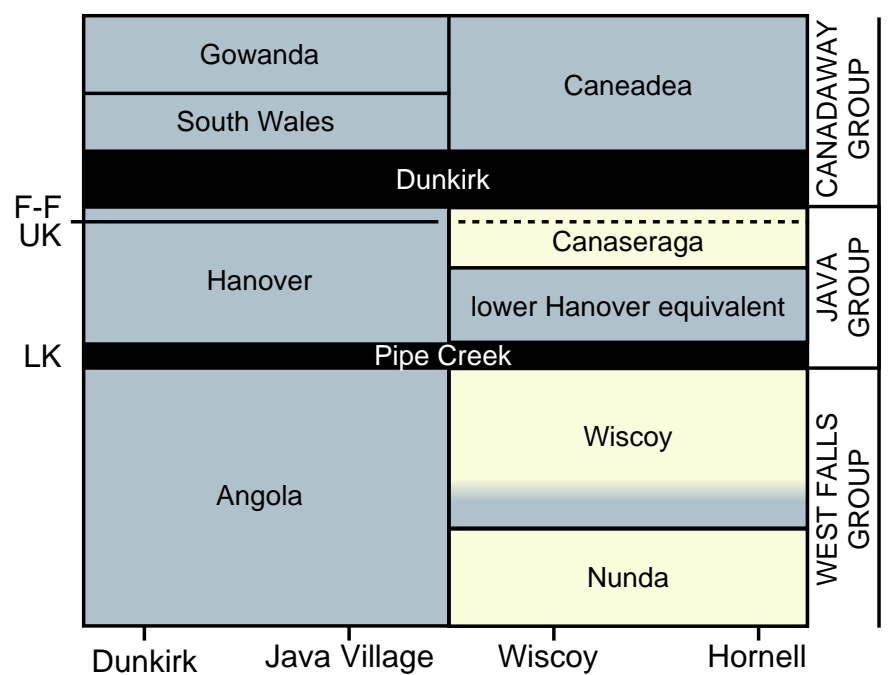

Shale/Silt $\square$ Silt/Sand 
Figure 3,1 column
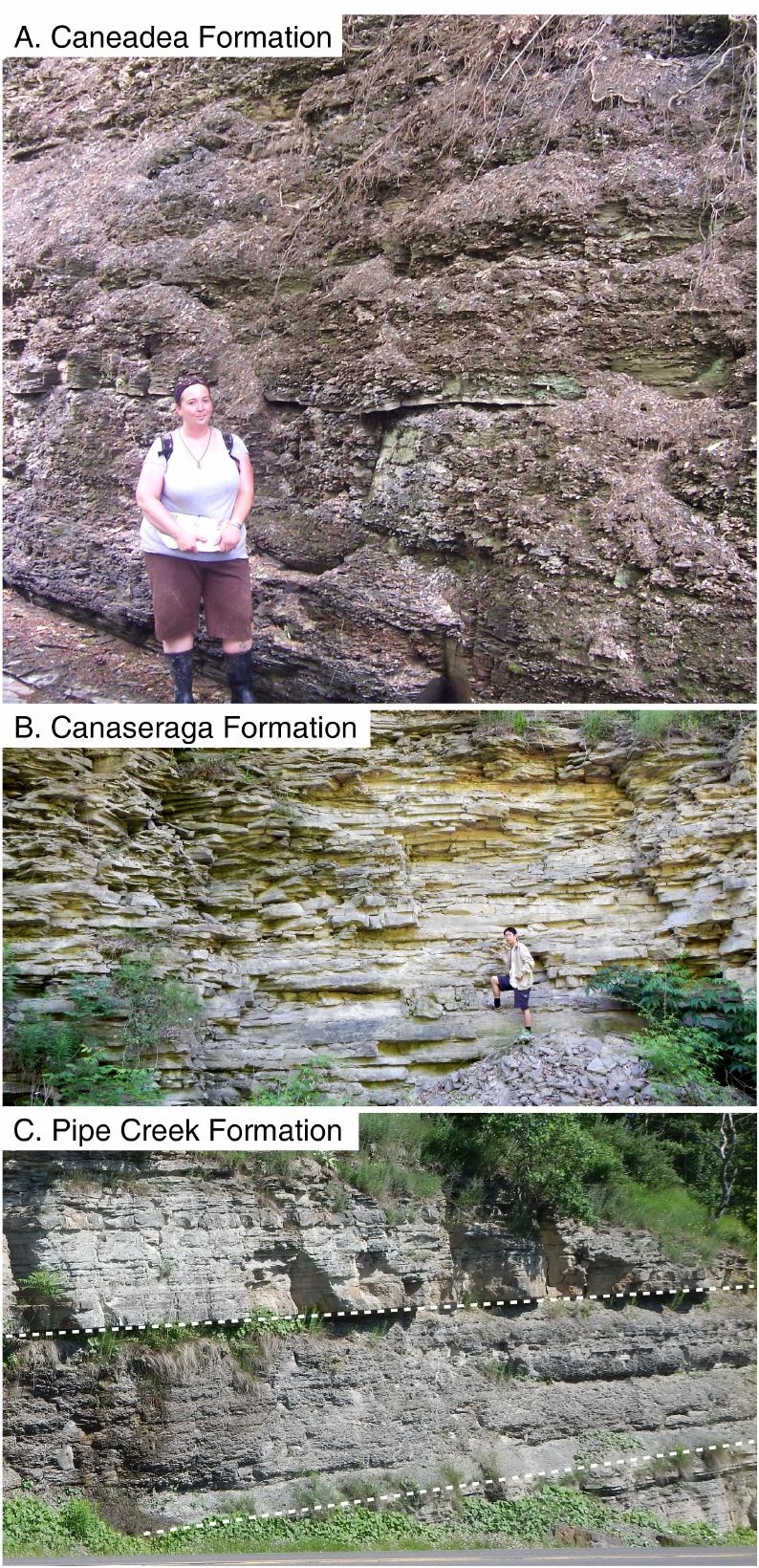

D. Wiscoy Formation Pretr.

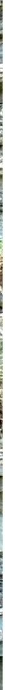


Figure 4

2 column

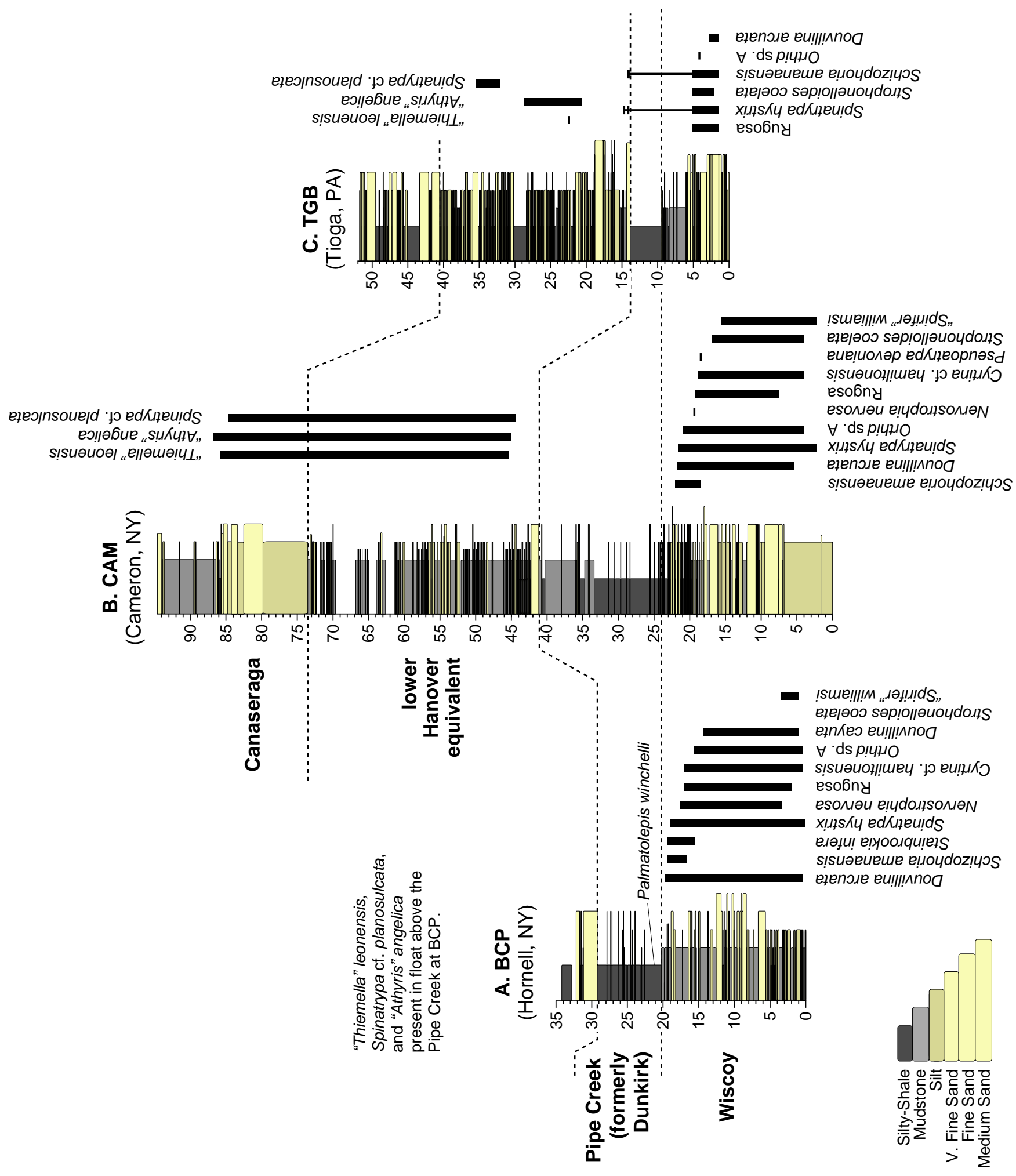


Figure 5, 2 column

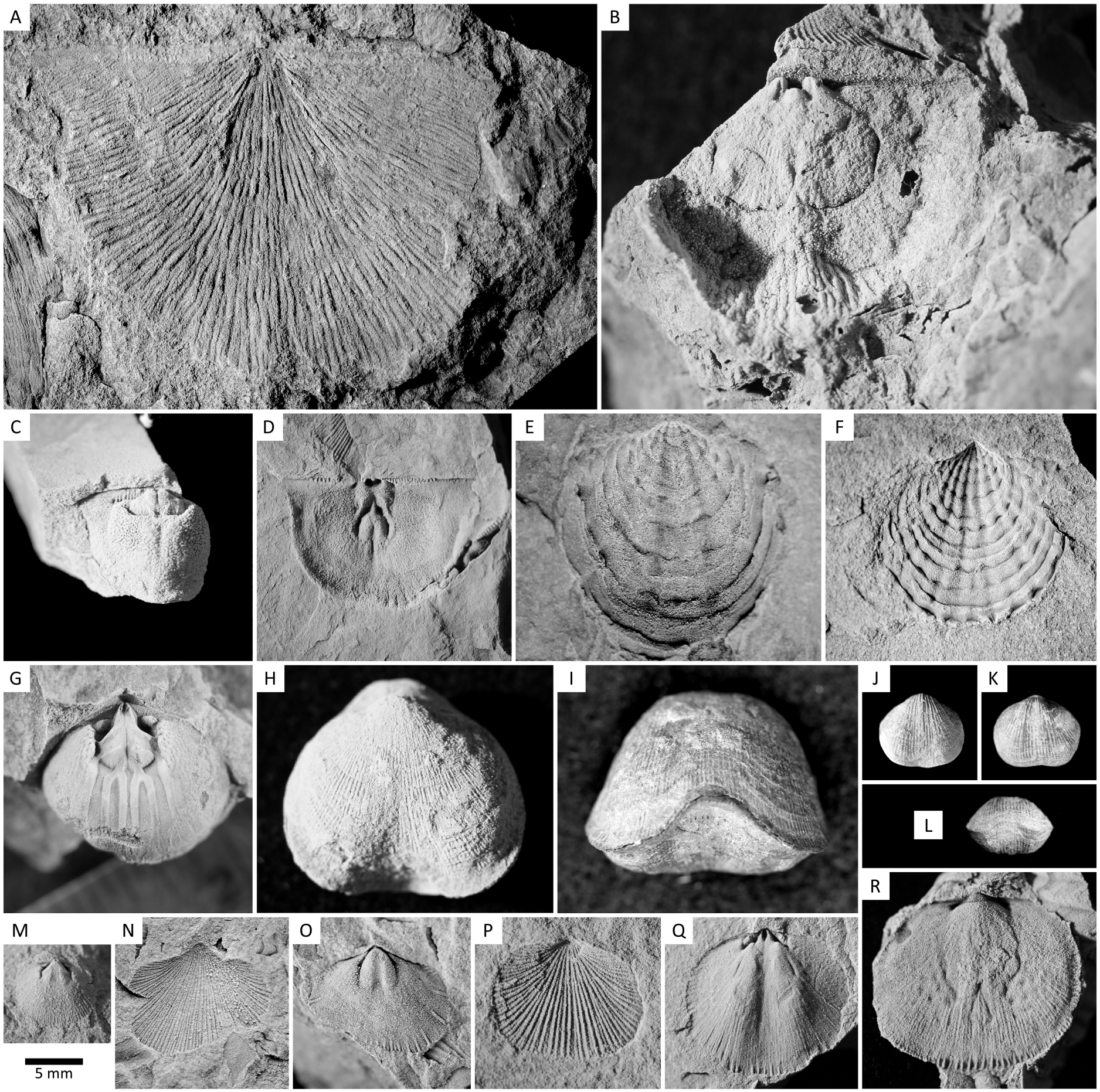


Figure 6

1 column

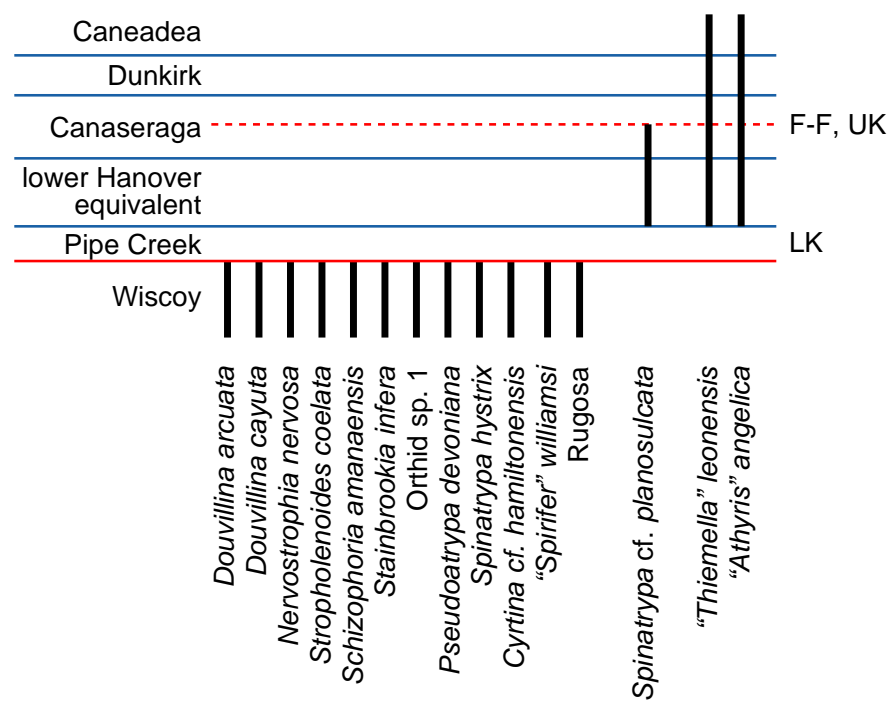




$$
\text { i }
$$




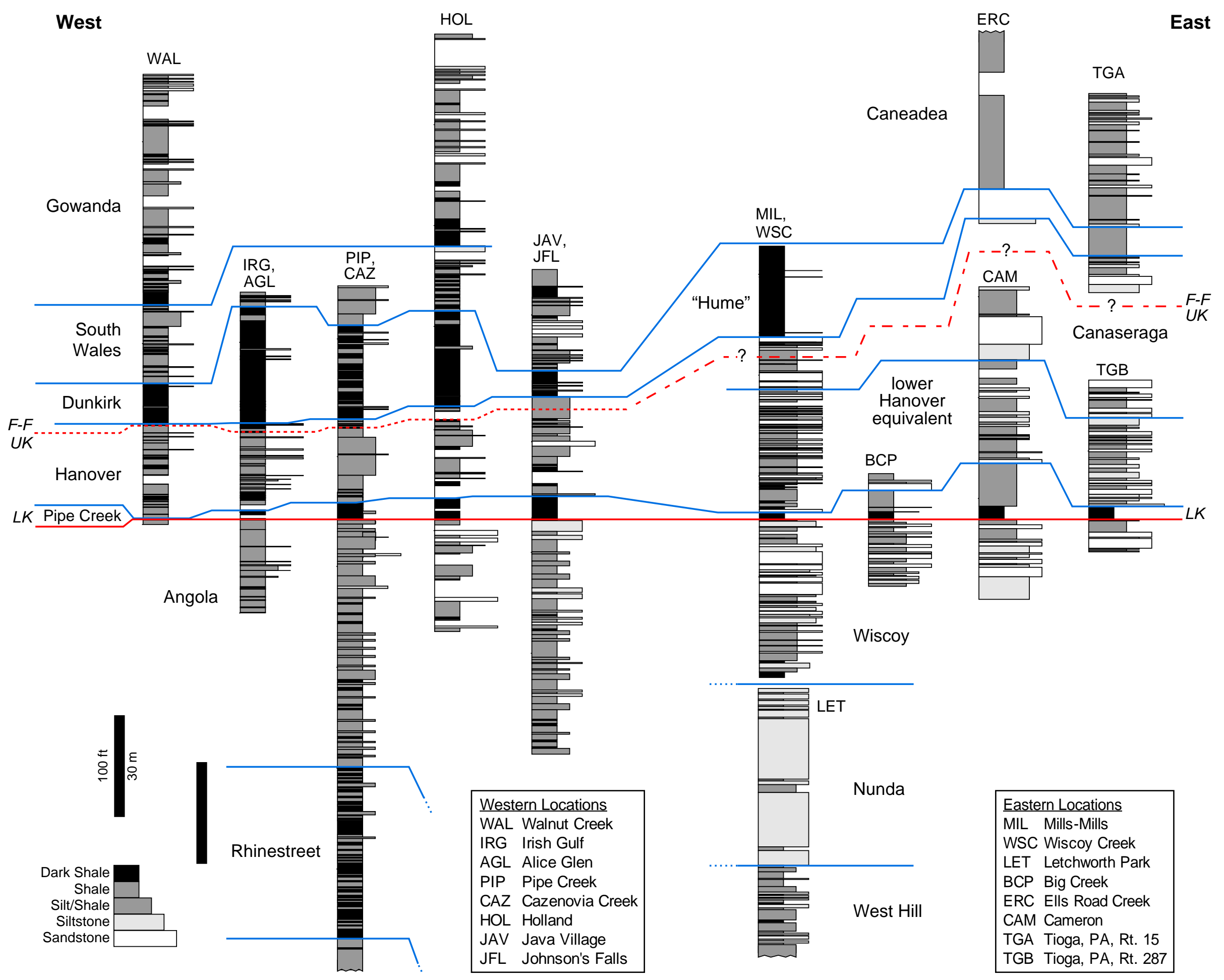

Al Walnut Creek

novia Creek

AV Java Village

FL Johnson's Falls 
Figure 9

1.5 column

B. Steuben Co.

Well 21450

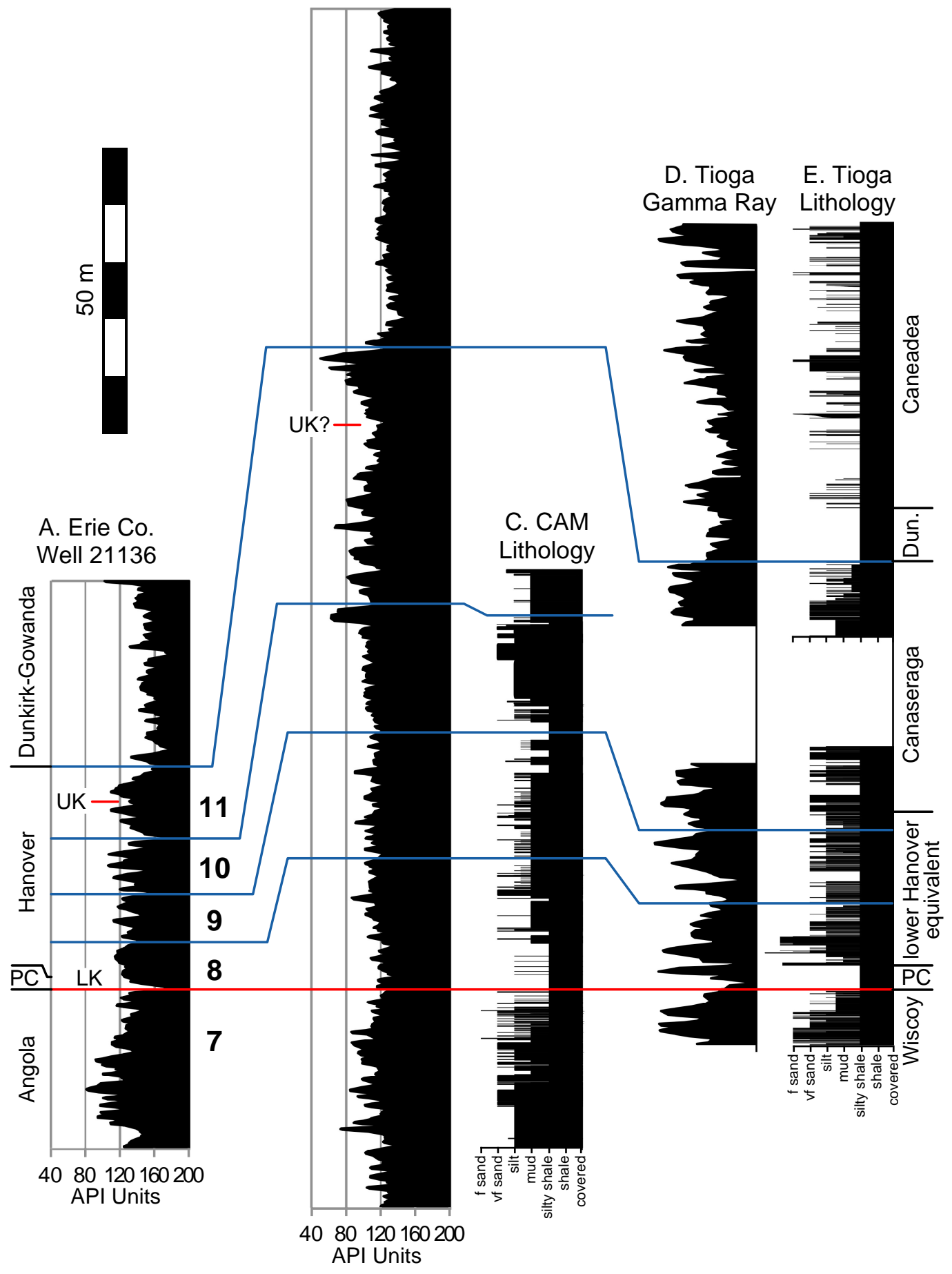

